\title{
Design and Performance of Atomizing Nozzles for Spray Calcination of High-Level Wastes
}

\author{
F. A. Miller \\ L. A. Stout
}

May 1981

Prepared for the U.S. Department of Energy under Contract DE-AC06-76RLO 1830

Pacific Northwest Laboratory

Operated for the U.S. Department of Energy

by Battelle Memorial Institute 


\title{
NOTICE
}

This report was prepared as an account of work sponsored by the United States Government. Neither the United States nor the Department of Energy, nor any of their employees, nor any of their contractors, subcontractors. or their employees, makes any warranty, express or implied, or assumes any legal liability or responsibility for the accuracy, completeness or usefulness of any information, apparatus, product or process disclosed, or represents that its use would not infringe privately owned rights.

The views, opinions and conclusions contained in this report are those of the contractor and do not necessarily represent those of the United States Government or the United States Department of Energy.

\author{
PACIFIC NORTHWEST LABORATORY \\ operated by \\ BATTELLF \\ for the \\ UNITED STATES DEPARTMENT OF ENERGY \\ Under Contract DE-AC06-76RLO 1830
}

\author{
Printed in the United States of America \\ Available from \\ National Technical Information Service \\ United States Department of Commerce \\ 5285 Port Royal Road \\ Springfield, Virginia 22151
}

Price: Printed Copys.

$\because$ Microfiche $\$ 3.00$

$\begin{array}{cc}\text {-Pages } & \begin{array}{c}\text { NTIS } \\ \text { Selling Price }\end{array} \\ & \\ 001-025 & \$ 4.00 \\ 026-050 & \$ 4.50 \\ 051-075 & \$ 5.25 \\ 076-100 & \$ 6.00 \\ 101-125 & \$ 6.50 \\ 126-150 & \$ 7.25 \\ 151-175 & \$ 8.00 \\ 176-200 & \$ 9.00 \\ 201-225 & \$ 9.25 \\ 226-250 & \$ 9.50 \\ 251-275 & \$ 10.75 \\ 276-300 & \$ 11.00\end{array}$


DESIGN AND PERFORMANCE OF ATOMIZING NOZZLES

FOR SPRAY CALCINATION OF HIGH-LEVEL WASTES

F. A. Miller

L. A. Stout

May 1981

Prepared for

the U.S. Department of Energy

under Contract DE-AC06-76RL0 1830

Pacific Northwest Laboratory

Richland, Washington 99352 

Sponsored by the U.S. Department of Energy (previously the U.S. Energy Research and Development Administration), the Pacific Northwest Laboratory has been developing a heated-wall spray calcination process for drying high-level radioactive waste solutions and slurries. A key aspect of high-level liquidwaste spray calcination is waste-feed atomization by using air atomizing nozzles. Atomization substantially increases the heat transfer area of the waste solution, which enhances rapid drying.

Experience from spray-calciner operations has demonstrated that nozzle flow conditions that produce $70-\mu$ median-volume-diameter or smaller spray droplets are required for small-scale spray calciners (drying capacity less than $80 \mathrm{~L} / \mathrm{h}$ ). For large-scale calciners (drying capacity greater than $300 \mathrm{~L} / \mathrm{h}$ ), nozzle flow conditions that produce 100- $\mu$ median-volume-diameter or smaller spray droplets are required. Air atomizing nozzles have provided the necessary sized droplets for proper spray calciner operation with few problems. The spray droplet sizes produced are inversely proportional to the gas-toliquid flow ratio both on mass basis and volume basis. Mass flow ratios of 0.2 to 0.4 , depending on nozzle size, are required for proper operation of internal-mix atomizing nozzles.

Both internal-mix and external-mix nozzles have been tested at PNL. External-mix nozzles require a higher air-to-liquid flow than do internal-mix nozzles. Also, external-mix nozzles can produce a few large droplets at the center of the spray pattern at higher liquid flow rates, which may cause an accumulation of damp calcine on the calciner cone section. However, externalmix nozzles can be used with nonpressurized feed systems, such as air-lift feed systems, and do not experience the abrasive wear that occurs with internal-mix nozzles. Due to the lower airflow requirements and fewer large droplets produced, the internal-mix nozzle has been chosen for primary development in the spray calciner program at PNL.

Several nozzle air-cap materials for internal-mix nozzles have been tested for wear resistance. Results show that nozzle air caps of stainless steel and 
Cer-vit ${ }^{\circledR}$ (a machineable glass ceramic) are susceptible to rapid wear by abrasive slurries, whereas air caps of alumina and reaction-bonded silicon nitride show only slow wear. Based on extrapolated wear measurements, the frequency of nozzle replacement for reaction-bonded silicon nitride required as a result of excessive air-cap wear is $>25 d$ and up to several months. This frequency depends on whether a straight-line extrapolation or a parabolic extrapolation is made from the test data. Actual wear measurements indicate that the wear rate occurs more rapidly the first $30 \mathrm{~h}$ and then decreases; therefore, a parabolic wear-rate curve is indicated. Longer-term testing (>25 d) is necessary to determine more accurately the actual frequency of nozzle replacement.

Atomizing nozzle air caps of alumina are subject to fracture from thermal shock, whereas air caps of silicon nitride and Cer-vit are not. Fractured nozzles are held in place by the air-cap retaining ring and continue to atomize satisfactorily. Therefore, fractures caused by thermal shocking do not necessarily result in nozzle failure. 
SUMMARY

FIGURES

TABLES

INTRODUCTION

CONCLUSIONS

NOZZLE DESCRIPTION AND OPERATIONS

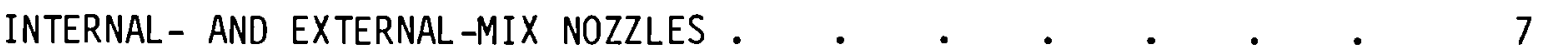

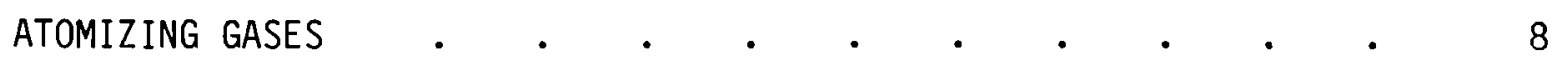

COMPARISON OF INTERNAL AND EXTERNAL-MIX NOZZLES $\quad$ • $\quad$ • $\quad$ • $\quad$ • 9

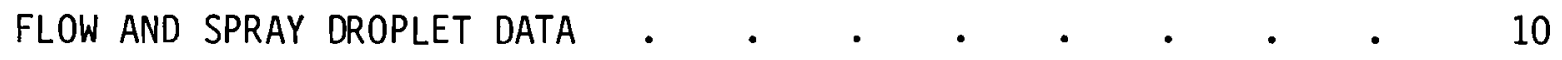

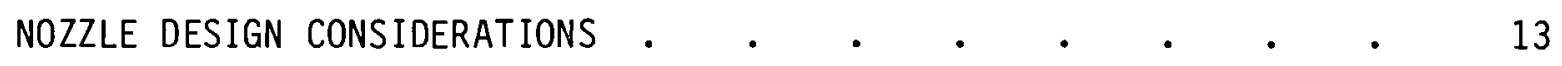

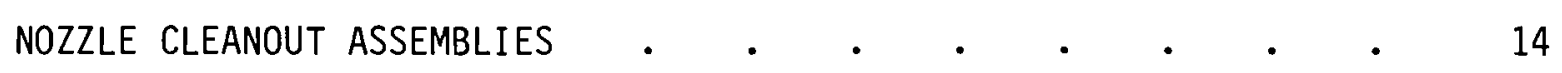

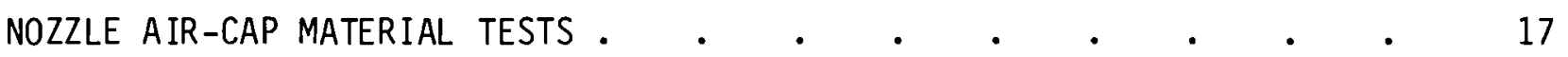

NOZZLE AIR-CAP WEAR AND THERMAL SHOCK PROBLEMS • • • • • 17

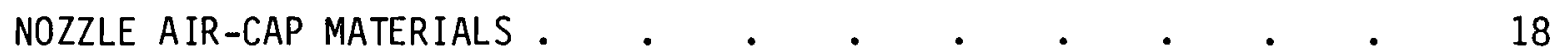

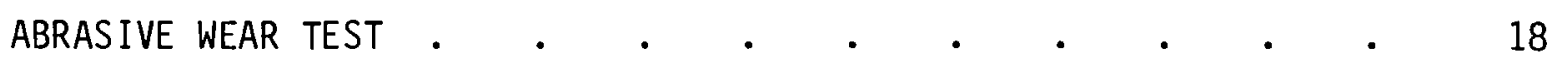

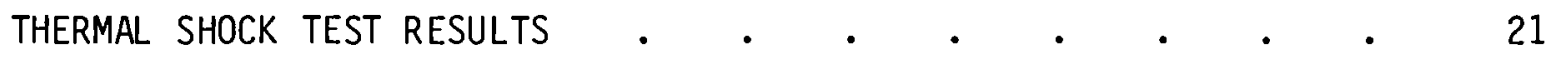

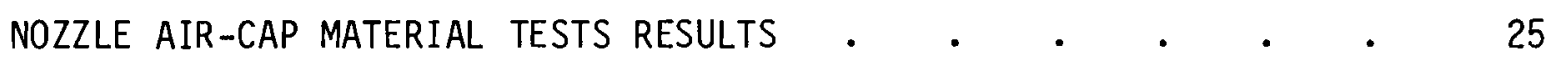

Abrasive Wear Tests Results . . . . . . . . 25

Thermal Shock Tests Results . . . . . . . . 27

FULL-SCALE-CALCINER NOZZLE AIR-CAP WEAR MEASUREMENTS . • • $\quad 31$

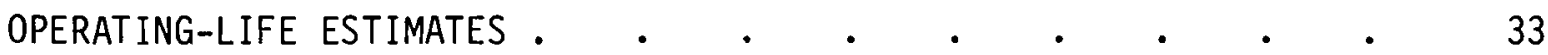

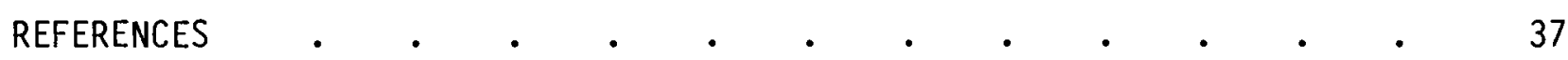




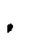




\section{FIGURES}

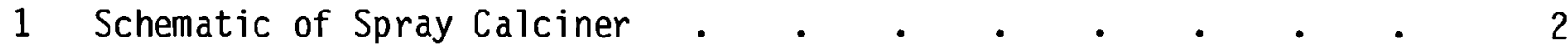

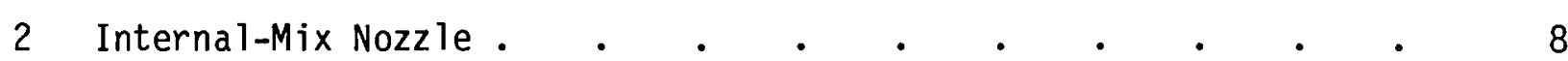

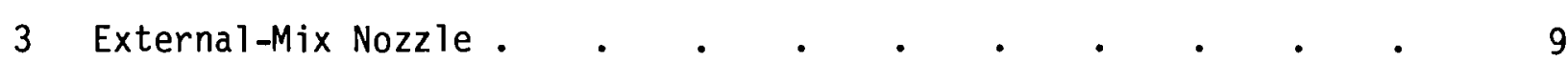

4 Examples of Poor and Good Aerodynamically Designed Nozzles • • 14

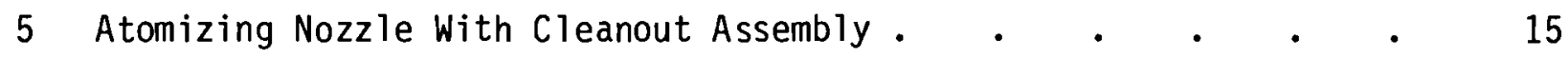

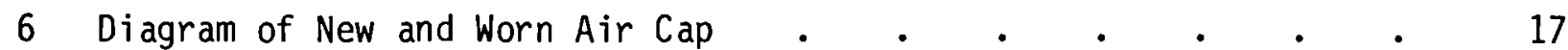

7 Schematic of Wear Test Equipment . . . . . . . . . 19

8 Air-Cap Wear Testing Station . . . . . . . . . . 20

9 Schematic Diagram of Thermal Shock Testing Equipment . . . $\quad 23$

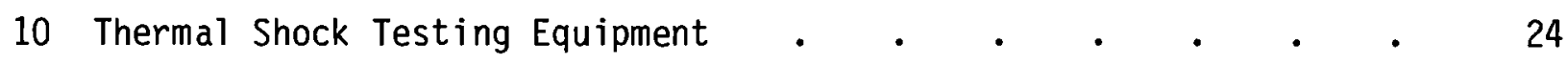

11 Location of Thermocouple in Nozzle Assembly . . . . . . $\quad 25$

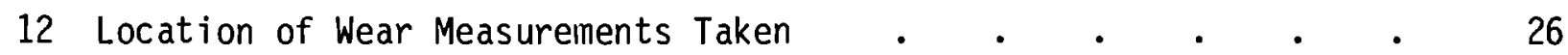

13 New and Worn Air Caps With Corresponding Molds of the Air-
Cap Interior $. \quad . \quad . \quad . \quad . \quad . \quad . \quad . \quad . \quad 27$

14 Air Caps Broken by Thermal Shock . . . . . . . . . 30

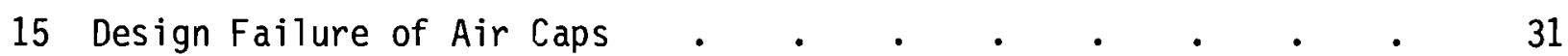

16 Nozzle Air-Cap Operating Life Extrapolation . . . . . . . 34 


\section{$\underline{\text { TABLES }}$}

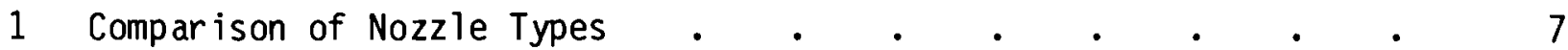

2 Flow and Droplet Size Data for Internal-Mix Nozzles . . . 11

3 Flow and Droplet Size Data for External-Mix Nozzles . . . 12

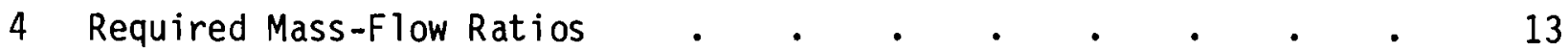

5 Simulated Waste Feed Composition . . . . . . . . . 21

6 Wear Testing Run Parameters . 6 .

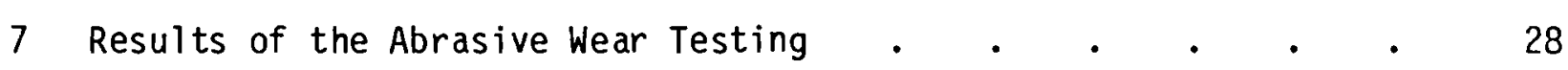

8 Results of the Thermal Shock Testing . . . . . . . . . 29

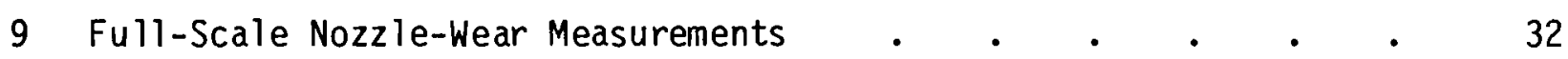

10 Feed Slurry Composition Used During Nozzle-Wear Measurement

11 Comparison of Physical Properties for Reaction-Bonded and HotPressed Silicon Nitride $. \quad . \quad . \quad . \quad . \quad . \quad . \quad . \quad . \quad 33$ 


\section{INTRODUCTION}

The Pacific Northwest Laboratory (PNL) has developed under the sponsorship of the U.S. Department of Energy the spray calciner to solidify liquid radioactive wastes. The spray calcination process is extremely versatile for drying widely varying waste compositions (Bonner, Blair and Romero 1976). At PNL, the spray calciner has been operated coupled to in-can melters and ceramic melters for the production of a vitrified product, and has also produced calcine for pellets and associated alternate waste forms.

One of the important phases in spray calcination is the atomization of waste feed by using spray nozzles. To prevent caking, the liquid waste must be dispersed into droplets small enough to dry before striking the spray-chamber wall or the cone at the bottom of the calciner. Good atomization increases the heat transfer area of the droplets and hastens their drying.

In conventional spray drying, a secondary stream of heated air or steam conveys heat to the droplets being dried. Since the large volume of secondary gas required by this process becomes an additional effluent that requires decontamination, a heated-wall spray dryer has been developed. During operation of this equipment, liquid waste is pumped to a spray nozzle and atomized with compressed air. The atomized droplets are then dried and partially calcined (converted to oxides) by radiative and convective heat transfer as they fall through the heated chamber. The wall temperature of the chamber is held between 400 and $800^{\circ} \mathrm{C}$, depending on the waste composition. Vibrators that impact against the sides of the spray chamber are periodically operated to minimize the hold-up of the dried powder. After passing through the heated spray chamber, powder entrained by the offgas stream is removed by sintered metal filters. A periodic pulse of blowback air, counter-current to the offgas stream flow, cleans these filters. The powder removed from the filters falls through the cone section of the spray calciner and is discharged along with the powder that falls directly from the spray chamber. This process is illustrated in Figure 1. 


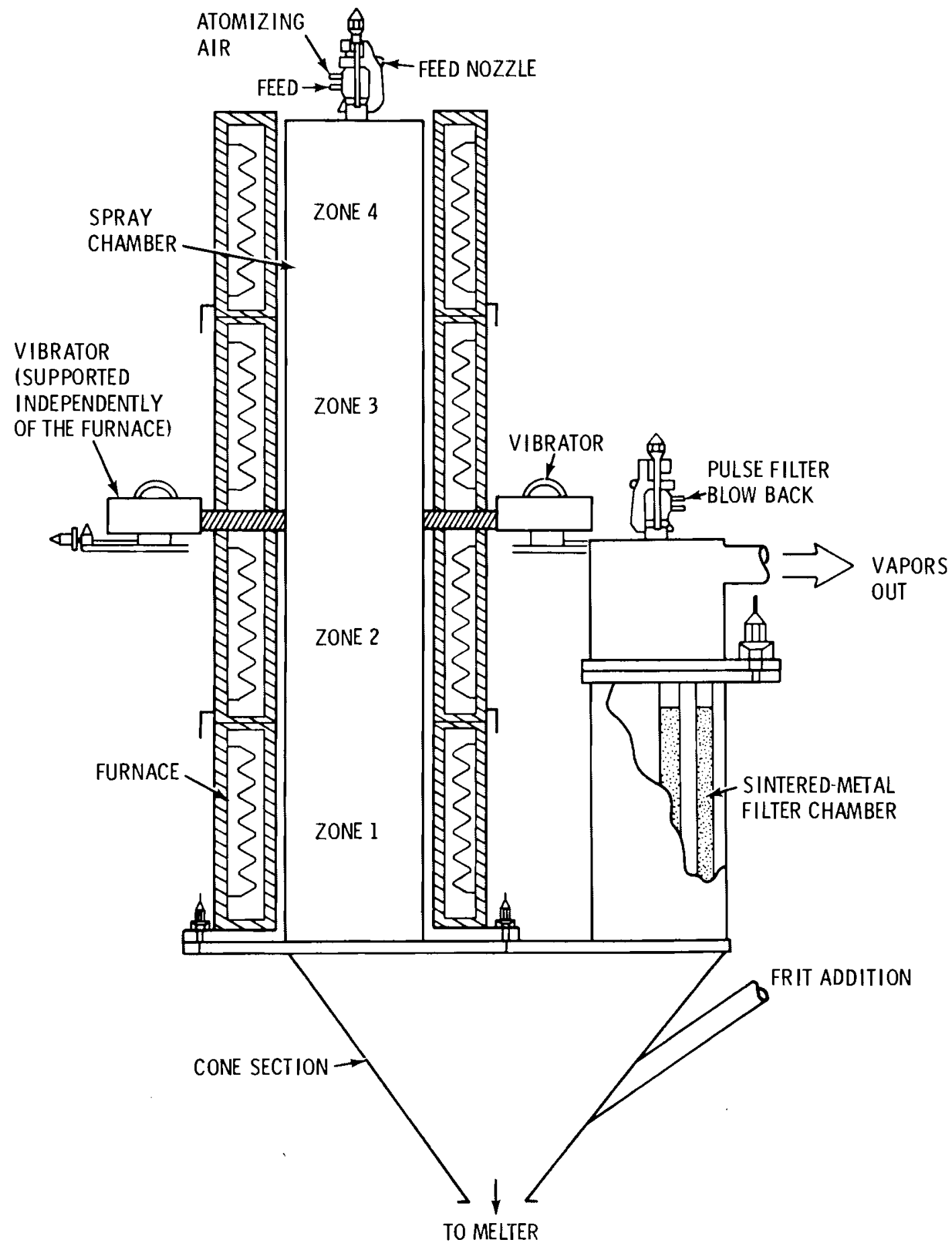

FIGURE 1. Schematic of Spray Calciner 
This document summarizes the experience gained in the design, operation, and performance of atomizing spray nozzles used during the development of the spray calciner. Also, methods and results of thermal shock and wear tests for selected nozzle air-cap materials are reported. 


\section{CONCLUSIONS}

Conclusions drawn from spray nozzle design, operation, performance, and materials tests during the development of the spray calciner follow:

- Steam, hot air, and ambient-temperature air have been evaluated as atomizing gases. Both steam and preheated air cause plugging in conventional internal- and external-mix nozzles. Therefore, ambient-temperature air has been the gas used for atomization at PNL. However, if desired, steam or hot air could be used for atomization with an external-mix nozzle that uses internal nozzle cooling.

- Nozzle cleanout assemblies are not required for nozzles with air-cap orifices of $0.64 \mathrm{~cm}$ or larger.

- Compared to internal-mix nozzles, external-mix nozzles require a much higher air-to-liquid flow. Also, external-mix nozzles can produce a few large droplets at the center of the spray pattern at higher liquid flow rates that may cause an accumulation of damp calcine on the calciner cone section. However, external-mix nozzles can be used with nonpressurized feed systems, such as air-lift feed systems, and do not experience the abrasive wear that occurs with internal-mix nozzles.

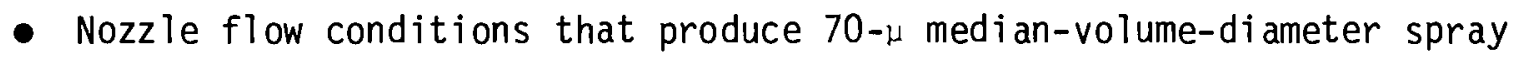
droplets or smaller are required for small-scale calciners (drying capacity $<80 \mathrm{~L} / \mathrm{h}$ ). For large-scale spray calciners (drying capacity $>300 \mathrm{~L} / \mathrm{h})$, nozzle flow conditions that produce 100- $\mu$ median-volumediameter spray droplets or smaller are required.

- The spray droplet size is inversely proportional to the gas-to-liquid flow ratio both on a mass basis and volume basis.

- Increased solids loading decreases the spray droplet size.

- Certain nozzle shapes cause excessive turbulence of the spray droplets that can result in dried solid accumulations. Nozzle designs 
that aerodynamically improve the spray pattern have minimized solid accumulations on the nozzle and spray-chamber lid.

- Nozzle-wear tests made using pilot-scale nozzles (0.32-cm air-cap orifice) have shown that nozzle air caps of stainless steel and Cer-vit are susceptible to rapid wear from an abrasive feed slurry, whereas air caps of $96 \%$ alumina and reaction-bonded silicon nitride show only slow wear.

- Nozzle-wear measurements of full-scale nozzles $10.79 \mathrm{~cm}$ air cap orifice) of $99 \%$ alumina show wear rates similar to the $96 \%$ alumina pilot-scale nozzles (slow wear), whereas full-scale nozzles of sintered silicon nitride show higher wear rates than the pilot-scale reaction-bonded silicon nitride. The different methods of ceramic formation are expected to have caused the difference in wear rates. Based on physical properties, hot-pressed silicon nitride is expected to have superior wear resistance to even reaction-bonded silicon nitride (hot-pressed silicon nitride was not available for testing).

- Nozzle air caps of 96 and $99 \%$ alumina are subject to fracture from thermal shock, whereas air caps of silicon nitride and Cer-vit are not. Fractured nozzles are held in place by the air-cap retaining ring and continue to atomize satisfactorily. Therefore, fractures caused by thermal shocking do not necessarily result in nozzle failure.

- Maintenance for atomizing nozzles consists of occasional nozzle replacement due to gradual wear of the air-cap orifice. Based on extrapolated wear measurements, the operating life of a reactionbonded silicon nitride nozzle is between $25 \mathrm{~d}$ and several months, depending on whether a straight-line extrapolation or a parabolic extrapolation is made. Actual wear measurements indicate that the wear occurs most rapidly in the first $30 \mathrm{~h}$ and then decreases; therefore, a parabolic wear rate curve is believed to apply. Longer-term testing $(>25$ d) is necessary to determine the actual lifetime of a nozzle. 


\section{NOZZLE DESCRIPTION AND OPERATIONS}

In this section, types of atomizing nozzles are described and nozzle operating experience at PNL is discussed.

\section{INTERNAL - AND EXTERNAL-MIX NOZZLES}

Most atomizing nozzles fall into three general categories: pressure, rotary, and two-fluid. Some comparisons of these nozzles are listed in Table 1. Because of the simplicity (nonmechanical) and fine atomizing characteristics of the two-fluid nozzles, they have been chosen for development in the heated-wall spray calciner at PNL.

Two types of two-fluid atomizing nozzles have been tested for the spraydrying of waste feeds: internal mix and external mix. In an internal-mix nozzle, pressurized liquid contacts with pressurized air in a small internal chamber. The fluid is then sprayed through an orifice (see Figure 2). Although the air velocity is very high, the liquid velocity is low. As a result of the shearing action of the high-speed air upon the slow-moving liquid, atomization occurs.

\section{TABLE 1. Comparison of Nozzle Types}

\begin{tabular}{|c|c|c|c|}
\hline Nozzle & Design Features & Advantages & Disadvantages \\
\hline Pressure & $\begin{array}{l}\text { Source of atomizing } \\
\text { energy is from fluid } \\
\text { being atomized. }\end{array}$ & $\begin{array}{l}\text { Simplicity and low } \\
\text { cost. }\end{array}$ & $\begin{array}{l}\text { Limited tolerance for } \\
\text { solids; susceptible } \\
\text { to plugging due to } \\
\text { small or ifices; sus- } \\
\text { ceptible to erosion. }\end{array}$ \\
\hline Rotary & $\begin{array}{l}\text { Liquid is fed to a } \\
\text { rotating surface. } \\
\text { Liquid is thrown out } \\
\text { at } 90^{0} \text { to the axis } \\
\text { of rotation. }\end{array}$ & $\begin{array}{l}\text { Rotating velocity } \\
\text { determines drop size } \\
\text { independent ly of } \\
\text { feed flow. }\end{array}$ & $\begin{array}{l}\text { Mechanical complexity } \\
\text { of rotating equip- } \\
\text { ment; radial dis- } \\
\text { charge. }\end{array}$ \\
\hline Two-Fluid & $\begin{array}{l}\text { Gas impinges on flow } \\
\text { of liquid and sup- } \\
\text { plies energy for } \\
\text { atomization. }\end{array}$ & $\begin{array}{l}\text { Liquid-flow passages } \\
\text { can be large and, } \\
\text { hence, minimized } \\
\text { plugging; fine atom- } \\
\text { ization possible at } \\
\text { low feed pressures. }\end{array}$ & $\begin{array}{l}\text { Because gas is also } \\
\text { accelerated, energy } \\
\text { efficiency is inher- } \\
\text { ently lower than that } \\
\text { of other nozzles. }\end{array}$ \\
\hline
\end{tabular}




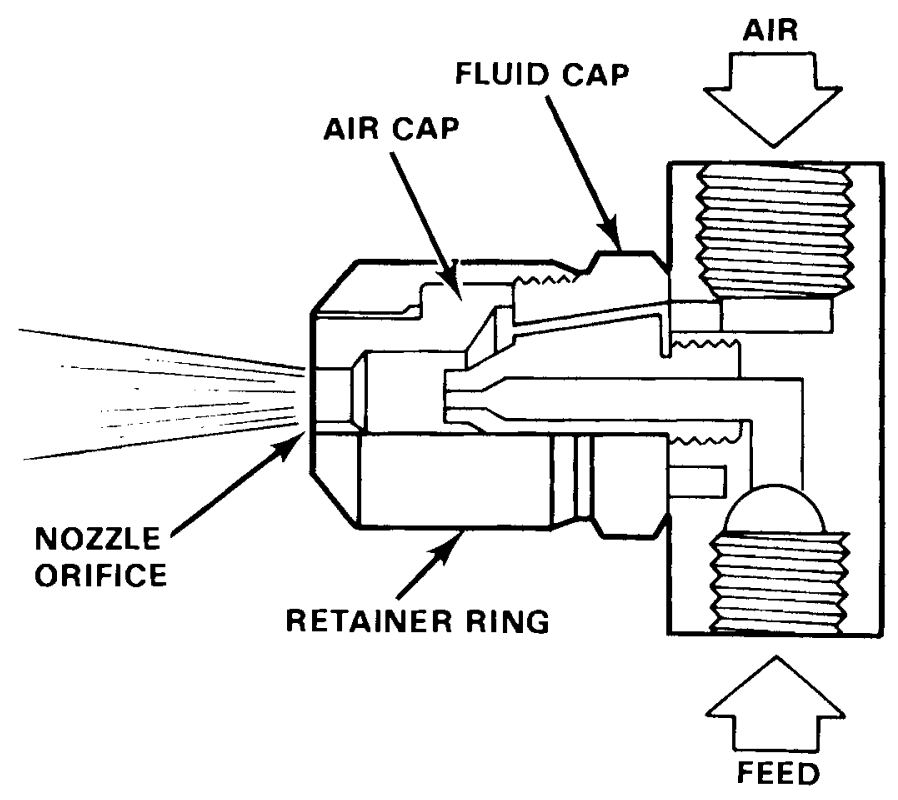

FIGURE 2. Interna 1-Mix Nozzle

An external-mix nozzle exhausts pressurized air around the liquid feed outlet and siphons the liquid through the nozzle (see figure 3). The air impacts upon the liquid outside the nozzle to break the liquid into droplets. Operating an external-mix nozzle with a nonpressurized feed system results in a higher air-to-liquid flow velocity, and therefore finer atomization than that in the same nozzle with a pressurized feed system.

\section{ATOMIZING GASES}

Steam, hot air, and ambient--temperature air have been evaluated as atomizing gases in internal- and external-mix nozzles. Both steam and preheated air cause nozzle plugging in internal-mix nozzles by drying the waste in the nozzle (Bonner, Blair and Romero 1976). Conventional external-mix nozzles are also heated excessively by hot air or steam and can plug from waste dried in the nozzle. Therefore, ambient-temperature air has been the gas used for atomization at PNL. However, if desired, hot air or steam could be used for atomization with an external-mix nozzle if the nozzle is cooled internally to prevent the feed from drying in the nozzle. This has been demonstrated at Karlsruhe, Germany (Kanfmah et al. 1976). 


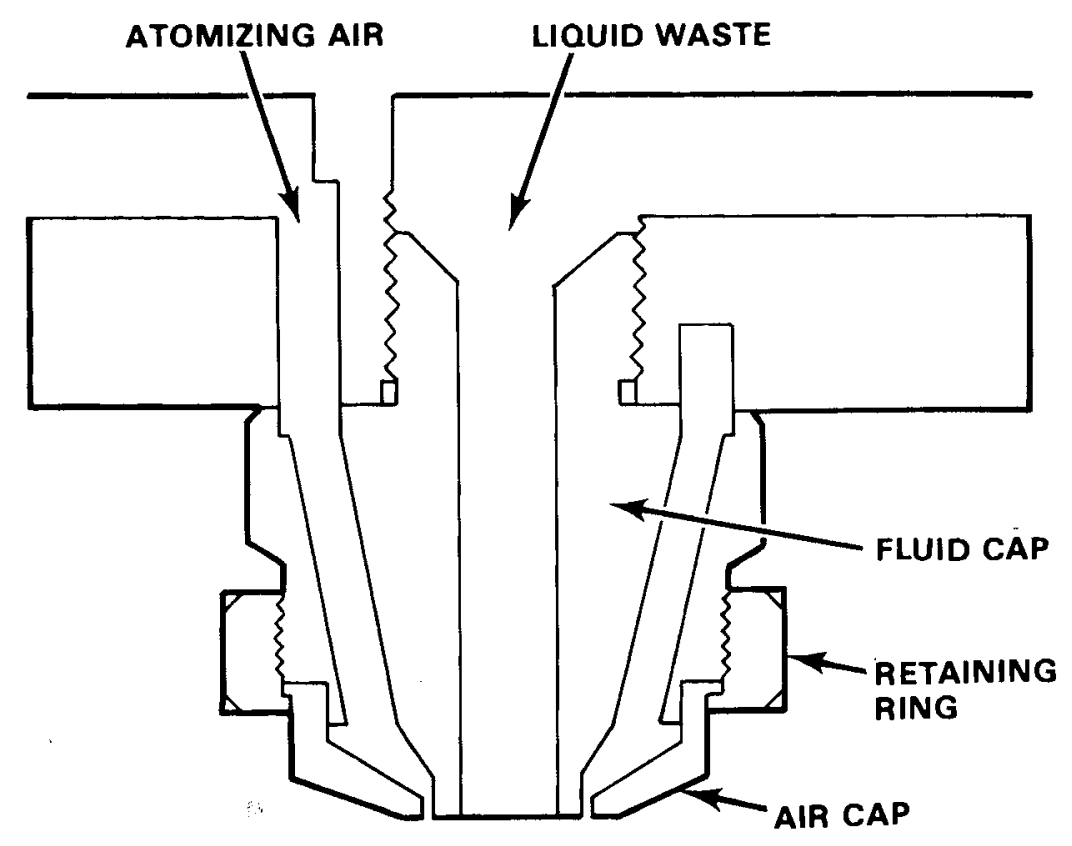

FIGURE 3. External-Mix Nozzle

Pressure and flow measurements of the atomizing air are important. In-cell measurements of the pressure and flow can be eliminated by sizing the air piping to minimize pressure drop and measuring both the pressure and flow at appropriate points in the out-of-cell air piping.

For an internal-mix nozzle, a pressure switch should be interlocked with the feed-pump power supply to turn off the pump if the atomizing air pressure drops below a minimum value. This will prevent waste feed from being forced into the atomizing air-line if the nozzle air-cap orifice becomes plugged and the waste-feed pressure exceeds the atomizing air pressure. In addition, an anti-backflow device should be installed in the air line. This risk does not occur with external-mix nozzles.

\section{COMPARISON OF INTERNAL - AND EXTERNAL-MIX NOZZLES}

Compared to internal-mix nozzles, external-mix nozzles have a disadvantage in that a much higher air-to-liquid flow is needed for operation, which requires 1 arger-capacity offgas treatment equipment. Also, external-mix 
nozzles tend to produce a few large droplets at the center of the spray pattern at higher liquid-flow rates, which may cause an accumulation of damp calcine on the calciner cone section. The number of large droplets can be minimized by maintaining a sufficient liquid-siphon height. The necessary siphon height must be determined by testing for individual calciner chamber heights and for varied flow rates. In addition, since the waste feed must be siphoned by an external-mix nozzle, feeds with a large percentage of solids are more likely to cause plugging in external-mix nozzles than internal-mix nozzles.

Despite these disadvantages, some advantages for the use of external-mix nozzles exist. A nonpressurized feed system, such as an air-lift-type feed system, can be used. This eliminates the need for a mechanical pump. Also, with an internal-mix nozzle, a small risk exists that waste feed can be forced into the atomizing air line if the air-cap orifice simultaneously becomes plugged and the pressure of the feed is exceeded. This risk does not exist with an external-mix nozzle. Finally, the abrasive wear experienced with internal-mix nozzles is not nearly as severe with external-mix nozzles since high-velocity air contacts with the waste feed outside the nozzle.

Due to the lower airflow requirements and fewer large droplets produced, the internal-mix nozzle has been chosen for primary development in the spray calciner at PNL.

\section{FLOW AND SPRAY DROPLET DATA}

Atomizing-air and liquid-flow data at various pressures and for various sizes of internal- and external-mix nozzles are listed in Tables 2 and 3. Although these data are supplied by a nozzle manufacturer for water sprayed at room temperature, the data agree closely with flow measurements made for actual calciner operation with simulated waste feeds. These data serve only as a standardized reference since air- and liquid-pressure measurements for actual plant equipment will depend upon the location of the pressure sensors and additional system pressure drops. 
TABLE 2. Flow and Droplet Size Data for Internal Mix Nozzles(a)

\begin{tabular}{|c|c|c|c|c|c|c|c|}
\hline Nozz & Sizes & & & & & & Mass \\
\hline $\begin{array}{l}\text { Air-Cap } \\
\text { Orifice, }\end{array}$ & $\begin{array}{l}\text { Fluid Cap } \\
\text { Orifice. }\end{array}$ & $\begin{array}{l}\text { Liquid } \\
\text { Pressure. }\end{array}$ & $\begin{array}{l}\text { Liquid } \\
\text { Flow }\end{array}$ & $\begin{array}{l}\text { Air } \\
\text { Pressure, }\end{array}$ & $\begin{array}{l}\text { Air- } \\
\text { flow, }\end{array}$ & Estimated & $\frac{\text { Air Flow }}{\text { Mass }}$ \\
\hline & & $\begin{array}{c}\text { psi } \\
\end{array}$ & & $\begin{array}{c}\text { psi } \\
\end{array}$ & SCFM, & MVD, (b) & Liquid Flow \\
\hline 0.318 & 0.254 & $\begin{array}{l}15(c) \\
15(c)\end{array}$ & & $\begin{array}{l}20 \\
22\end{array}$ & & $\begin{array}{r}100 \\
80\end{array}$ & \\
\hline & & & 61 & 25 & 4.18 & 120 & 0.150 \\
\hline & & 20 & 32 & 30 & 5.3 & 50 & 0.362 \\
\hline & & $\begin{array}{l}25(c) \\
25(c)\end{array}$ & & $\begin{array}{l}30 \\
35\end{array}$ & & $\begin{array}{r}130 \\
60\end{array}$ & \\
\hline 0.793 & 0.638 & 15 & 309 & 20 & 17.6 & 200 & \\
\hline & & $15(c)$ & & 25 & & 70 & \\
\hline & & $20(c)$ & & 25 & & 200 & \\
\hline & & 20 (c) & & 30 & & 70 & \\
\hline & & $20(c)$ & & 35 & & 50 & \\
\hline & & 25 & 436 & 30 & 22.5 & 250 & 0.113 \\
\hline & & 25 & 289 & 35 & 28.8 & 100 & 0.218 \\
\hline & & 25 & 173 & 40 & 35.3 & 50 & 0.446 \\
\hline 1.39 & 1.11 & 10 & 546 & 14 & 51 & 200 & 0.20 \\
\hline & & 10 & 387 & 16 & 61 & 110 & 0.34 \\
\hline & & $\begin{array}{l}10(c) \\
15(c)\end{array}$ & & $\begin{array}{l}20 \\
25\end{array}$ & & $\begin{array}{l}30 \\
70\end{array}$ & \\
\hline & & 20 & 750 & 26 & 72 & 255 & 0.210 \\
\hline & & $20(c)$ & 455 & $\begin{array}{l}30 \\
35\end{array}$ & 94 & $\begin{array}{r}100 \\
35\end{array}$ & 0.451 \\
\hline & & & & & & & \\
\hline
\end{tabular}

(a) Data for water sprayed at room conditions.

(b) MVD--Median Volume Diameter. Fifty percent of the total volume sprayed is made up of droplets with diameters less than the median value, and $50 \%$ are greater than the medi an diameter.

(c) Outside of the manufacturer's recommended operating range; higher air pressures can cause discontinuous liquid flow.

The estimated median volume diameters ${ }^{(a)}$ (see Tables 2 and 3) for spray droplets were also supplied by the nozzle manufacturer for water sprayed at room temperature. Since it is not practical to measure spray droplet sizes inside a $800^{\circ} \mathrm{C}$ calciner chamber, the flow conditions required to produce droplets small enough to dry before striking the spray chamber wall or cone section have been determined experimentally. These flow conditions have been correlated to the droplet sizes for water atomized at room temperature using Tables 2 and 3. For small-scale calciners (drying capacities less than

(a) Median Volume Diameter--Fifty percent of the total volume of sprayed liquid is made up of droplets with diameters less than the median value. Fifty percent have diameters greater than the median value. 
TABLE 3. Flow and Droplet Size Data for External Mix Nozzles(a)

\begin{tabular}{|c|c|c|c|c|c|c|c|}
\hline $\begin{array}{l}\frac{N o z z}{\text { Air-Cap }} \\
\text { Orifice, } \\
\mathrm{cm} \\
\end{array}$ & $\begin{array}{l}\text { Sizes } \\
\text { Fluid Cap } \\
\text { Orifice, } \\
\quad \mathrm{cm} \\
\end{array}$ & $\begin{array}{c}\text { Air } \\
\text { Pressure, } \\
\text { psi } \\
\end{array}$ & $\begin{array}{l}\text { Air- } \\
\text { Flow, } \\
\text { SCFM }\end{array}$ & $\begin{array}{l}\text { Liquid Siphon } \\
\text { Height, }(\mathrm{b})_{\mathrm{cm}}\end{array}$ & $\begin{array}{l}\text { Liquid } \\
\text { Flow, } \\
\mathrm{L} / \mathrm{h} \\
\end{array}$ & $\begin{array}{l}\text { Estimated } \\
\text { MVD } \\
\text { Range, } \mu \\
\end{array}$ & $\begin{array}{l}\text { Mass } \\
\text { Air Flow } \\
\text { Mass } \\
\text { Liquid Flow }\end{array}$ \\
\hline 1.11 & 0.635 & $\begin{array}{l}20 \\
20 \\
30 \\
30 \\
40 \\
40\end{array}$ & $\begin{array}{l}18.5 \\
18.5 \\
24.0 \\
24.0 \\
29.2 \\
29.2\end{array}$ & $\begin{array}{l}10.2 \\
20.3 \\
10.2 \\
20.3 \\
10.2 \\
20.3\end{array}$ & $\begin{array}{r}91 \\
55 \\
129 \\
98 \\
154 \\
124\end{array}$ & $\begin{array}{l}70-80 \\
50-60 \\
70-80 \\
60-70 \\
70-80 \\
60-70\end{array}$ & $\begin{array}{l}0.44 \\
0.73 \\
0.41 \\
0.54 \\
0.41 \\
0.51\end{array}$ \\
\hline 2.86 & 1.59 & $\begin{array}{l}20 \\
20 \\
25 \\
30 \\
40\end{array}$ & $\begin{array}{l}105 \\
105 \\
120 \\
135 \\
165\end{array}$ & $\begin{array}{l}10.2 \\
20.3 \\
20.3 \\
20.3 \\
20.3\end{array}$ & $\begin{array}{l}452 \\
245 \\
336 \\
333 \\
429\end{array}$ & $\begin{array}{l}200-250 \\
150-200 \\
150-200 \\
100-150 \\
100-150\end{array}$ & $\begin{array}{l}0.51 \\
0.94 \\
0.78 \\
0.89 \\
0.84\end{array}$ \\
\hline
\end{tabular}

(a) Data for water sprayed at room conditions.

(b) Liquid Siphon Height--Height of nozzle outlet above feed-tank liquid level.

$80 \mathrm{~L} / \mathrm{h})$, nozzle flow conditions are required that produce approximately $70-\mu$ (median volume diameter) or smaller droplets when water is sprayed at room temperature. For large-scale calciners (drying capacities greater than $300 \mathrm{~L} / \mathrm{h}$ ), nozzle flow conditions are required that produce approximately $100-\mu$ (median volume diameter) or smaller droplets when water is sprayed at room temperature. Table 4 indicates the air-to-liquid mass-flow ratios required to produce those droplet sizes for several atomizing nozzles.

Kaser (1969) has shown that the mass-median spray droplet size is strongly dependent on the ratio of liquid-to-gas flow rates, both on a mass and on a volume basis. The droplet size decreases with higher gas-to-liquid flow ratios. Also, the calciner temperature may influence the droplet size by causing rapid boiling and shattering of the droplets at high temperatures. Kaser (1969) also showed that a high percentage of solids in the waste feed produced smaller droplet sizes and that filtering out of solids causes the droplet size distribution to approach that of water at similar flow ratios. 
TABLE 4. Required Mass-Flow Ratios

\begin{tabular}{|c|c|c|c|c|}
\hline \multirow[b]{2}{*}{ Nozzle Type } & \multicolumn{2}{|c|}{ Nozzle Sizes } & \multirow[b]{2}{*}{$\begin{array}{c}\text { Droplet } \\
\text { MVD, (a) }{ }_{\mu}\end{array}$} & \multirow[b]{2}{*}{$\begin{array}{l}\text { Air-to-Liquid Mass- } \\
\text { Flow Ratios Required } \\
\text { to Obtain Droplet MVD }\end{array}$} \\
\hline & $\begin{array}{l}\text { Air-Cap } \\
\text { Orifice, } \\
\quad \mathrm{cm} \\
\end{array}$ & $\begin{array}{l}\text { Fluid Cap } \\
\text { Orifice, } \\
\quad \mathrm{cm} \\
\end{array}$ & & \\
\hline \multirow[t]{3}{*}{ Internal Mix } & 0.318 & 0.254 & $\begin{array}{r}70 \\
100\end{array}$ & $\begin{array}{l}0.3 \\
0.2\end{array}$ \\
\hline & 0.793 & 0.638 & $\begin{array}{r}70 \\
100\end{array}$ & $\begin{array}{l}0.3 \\
0.2\end{array}$ \\
\hline & 1.39 & 1.11 & 100 & 0.4 \\
\hline \multirow[t]{2}{*}{ External Mix } & 1.11 & 0.635 & 60 to 80 & 0.4 to 0.7 \\
\hline & 2.86 & 1.59 & 100 to 150 & 0.85 to 0.95 \\
\hline
\end{tabular}

(a) MVD--Mean Volume Diameter

\section{NOZZLE DESIGN CONSIDERATIONS}

Standard internal dimensions for the internal-mix nozzle fluid cap and the air cap supplied by the manufacturer have been used throughout the spray calciner development. However, external modifications have been made to improve aerodynamically the spray pattern to minimize solid accumulations on the nozzle and on the top of the spray chamber.

Experience has shown that certain nozzle shapes cause excessive turbulence at the nozzle exit or ifice that results in dried solid accumulations (Bonner, Blair and Romero 1976). In the same manner, nozzles that do not protrude through the top of the spray chamber at least $2.54 \mathrm{~cm}$ for full-scale calciners can also cause turbulence that results in dried solid accumulations on the top, inside surface of the spray chamber. Figure 4 illustrates examples of good and poor aerodynamic nozzle designs.

Another design consideration is the nozzle spray pattern, which must be compatible with the calciner spray-chamber diameter. A wide spray pattern in a sma11-diameter spray chamber will cause droplets to contact the heated wall before they are dry, resulting in a scale buildup. While no rule has been 


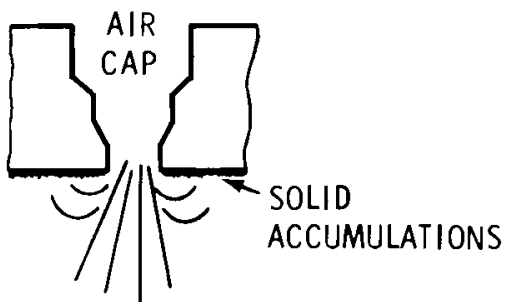

POOR AIR-CAP DESIGN

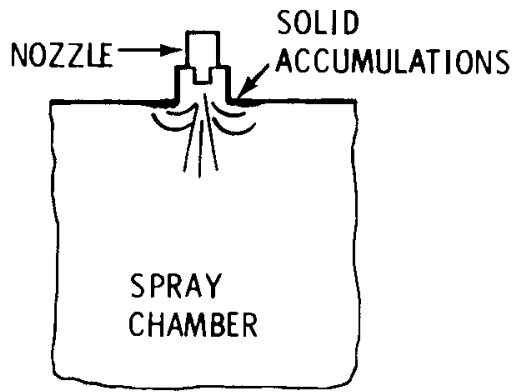

POOR NOZZLE ENTRANCE

DESIGN

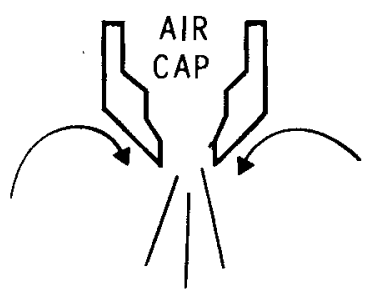

GOOD AIR-CAP DESIGN

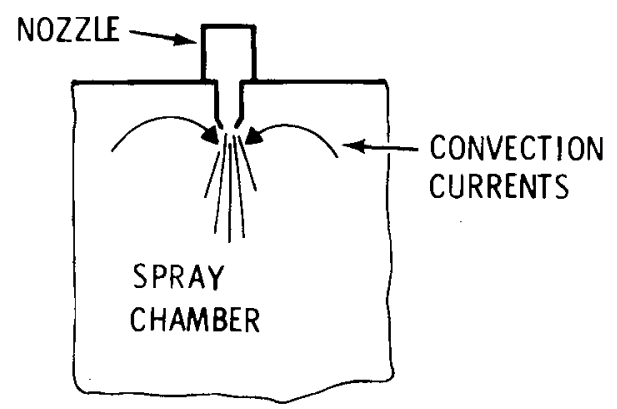

GOOD NOZZLE ENTRANCE

FIGURE 4. Examples of Poor and Good Aerodynamically Designed Nozzles

developed to determine the smallest-diameter chamber compatible with a particular nozzle, the diameter pattern in the chamber should be at least several inches 1 arger than the width of the spray pattern in free air to prevent direct impingement of the spray on the chamber wall.

\section{NOZZLE CLEANOUT ASSEMBLIES}

Nozzle cleanout assemblies have been used for nozzles with air-cap orifices $0.318 \mathrm{~cm}$ or smaller. These assemblies have a plunger that is extended through the air-cap orifice by compressed air. Figure 5 is a photograph of a nozzle with a cleanout assembly. While these cleanout assemblies have proven useful for small-scale calciners, they have never been used during operation of the full-scale calciner, which uses air-cap orifices 1 arger than $0.63 \mathrm{~cm}$. 


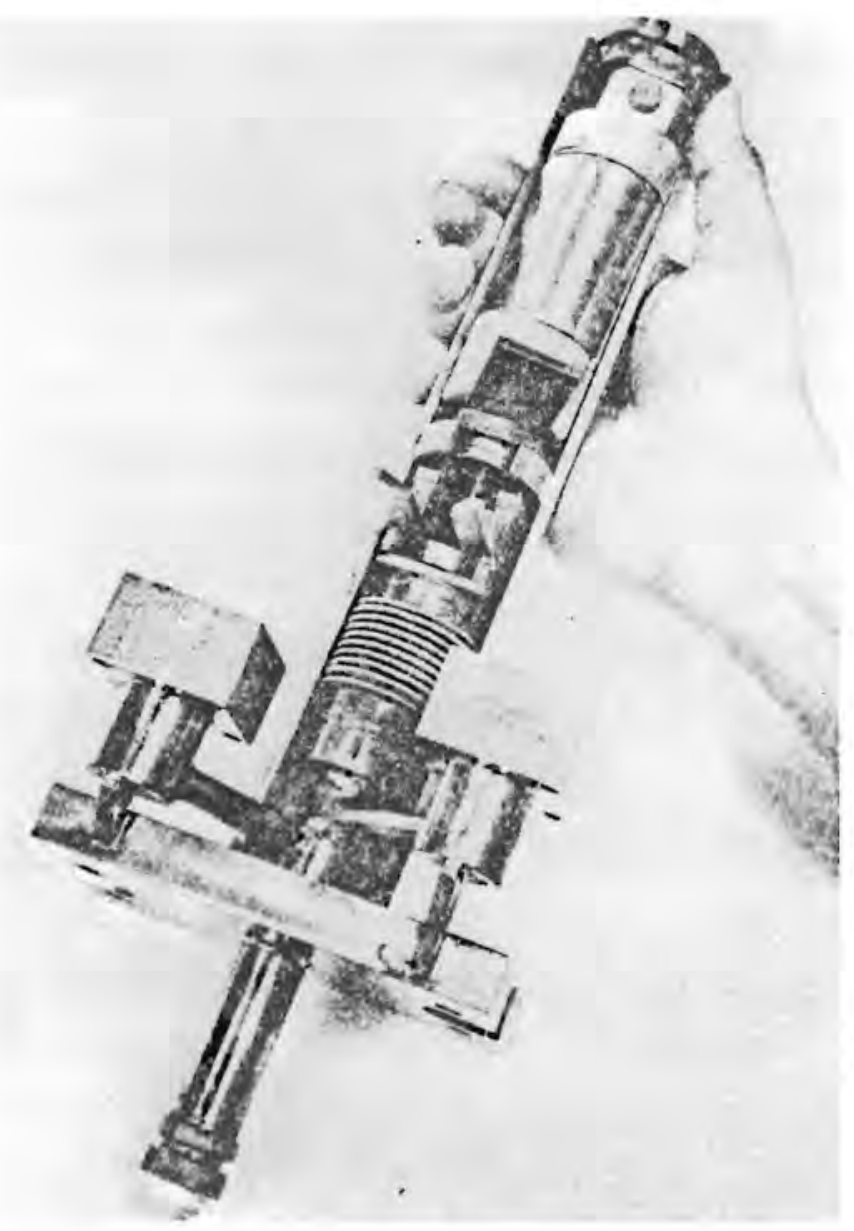

FIGURE 5. Atomizing Nozzle With Cleanout Assembly

Nozzle plugging in the full-scale calciner has occurred only once or twice in $3 \mathrm{yr}$ of intermittent testing. The cause of those pluggages was failure to precool the nozzle with demineralized water before startup of waste feeding. Precooling the nozzle with demineralized water prevents solids formation caused by flashing of the feed when the liquid reaches the hot feedline and nozzle during startup. Plugging in full-scale nozzles has never occurred when the nozzle has been precooled. In the event that a plug may occur, replacement of the nozzle would be probably more effective than providing a mechanism for cleaning the nozzle. 



\section{NOZZLE AIR-CAP MATERIAL TESTS}

Tests to determine the thermal shock and abrasive-wear resistance of several nozzle air-cap materials are described and the results discussed. Also, measurements of nozzle-wear from the actual operation of a full-scale spray calciner are summarized. Estimates of nozzle operating life are made from these results.

\section{NOZZLE AIR-CAP WEAR AND THERMAL SHOCK PROBLEMS}

The air cap of the internal-mix spray nozzle (see Figure 2) has been subject to failure from abrasive wear and, in some cases, thermal shock.

Abrasive wear occurs when the high-level liquid-waste slurry and atomizing air mix inside the air cap and impinge on the shoulder of the internal orifice at the exit of the nozzle. This impingement wears the air cap as shown in Figure 6 . If the orifice tip completely wears through, improper atomization of the liquid waste will result. Thus, the nozzle air cap must be resistant to this abrasive wear to increase its useful life.

Thermal shock failure occurs when a large temperature gradient across an air cap causes sufficient stress to break the air cap. During calciner operation, the spray chamber operates at about 700 to $800^{\circ} \mathrm{C}$ wall temperature and 300 to $600^{\circ} \mathrm{C}$ interior temperature. Thermal shock of the spray nozzle air cap can occur when one or both of the air or fluid flows are interrupted

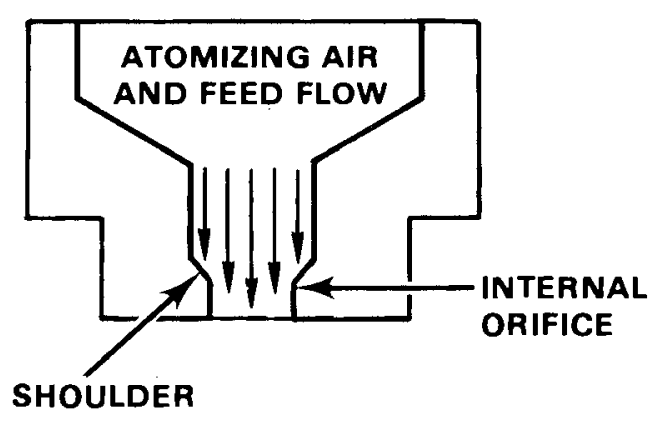

(a) NEW AIR CAP

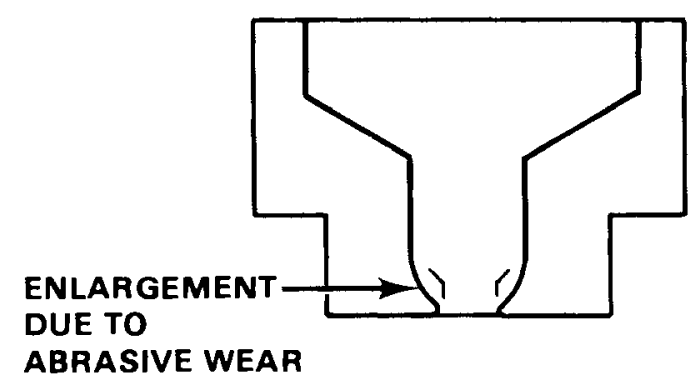

(b) WORN AIR CAP

FIGURE 6. Diagram of New and Worn Air Cap 
or started abruptly. For example, if the atomizing airflow is off during calciner heatup and then turned on suddenly, a cracked air cap could result.

\section{NOZZLE AIR-CAP MATERIALS}

Four air-cap materials were selected for testing of their relative thermal shock and wear-resistance characteristics. These included:

- reaction-bonded silicon nitride $\left(\mathrm{Si}_{3} \mathrm{~N}_{4}\right)$

- $96 \%$ alumina $\left(\mathrm{Al}_{2} \mathrm{O}_{3}\right)$

- Cer-vit ${ }^{\circledR}$ (a machineable glass ceramic)

- 303 stainless steel.

The type of nozzle used for testing was a Spraying Systems Company Nozzle Set-up No. 42, which has a $0.138-\mathrm{cm}$ air-cap orifice. This nozzle was used in a pilot-scale calciner with a normal operating liquid-feed rate of 20 to $40 \mathrm{~L} / \mathrm{h}$. For comparison, a lab-scale spray calciner in operation at PNL has a capacity of about $3 \mathrm{~L} / \mathrm{h}$ and uses a nozzle with a $0.119-\mathrm{cm}$ air-cap orifice; a full-scale spray calciner with a capacity of about $400 \mathrm{~L} / \mathrm{h}$ uses a nozzle with a $0.793-\mathrm{cm}$ air-cap orifice.

\section{ABRASIVE WEAR TEST}

A schematic diagram and photograph of the wear-test equipment is shown in Figures 7 and 8 , respectively. This equipment consisted of an 80-L slurry-feed tank that was constantly agitated. Liquid feed was pumped from the bottom of the tank to the spray nozzle and to the recycle line. Atomizing air was provided by a compressed-air supply from the test building and was metered through a pressure regulator and airflow rotameter. Two types of feed pumps were used during the project. Initially, a centrifugal pump was used, but its seals were rapidly worn through by the feed. A peristaltic pump was subsequently installed and no further difficulties were encountered. It should be noted that a peristaltic pump does impart a pulsing action to the fluid, but this was reduced by the use of a large recycle-to-feed ratio. Use of this ratio caused

\footnotetext{
${ }^{\circledR}$ Registered Trademark of Owens-Illinois, Inc.
} 


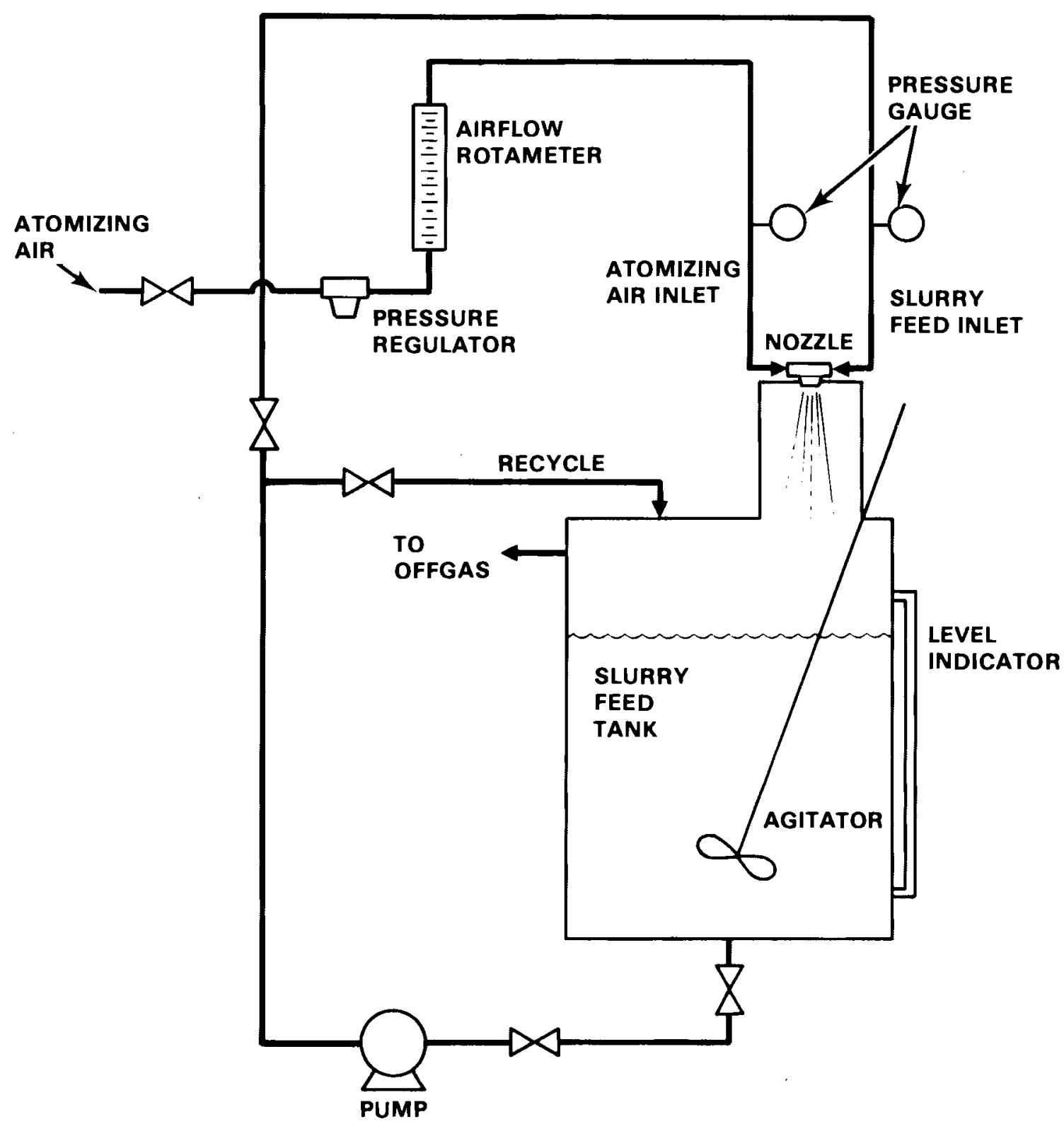

FIGURE 7. Schematic of Wear Test Equipment

the feed stream to become a continuous bleed stream off the recycle loop, thereby reducing its sensitivity to the pump action.

Due to its abrasive quality, simulated Savannah River high-level liquid waste (shown in Table 5) was chosen for use in the air-cap wear tests. This feed was atomized through each air cap under the set conditions given in 


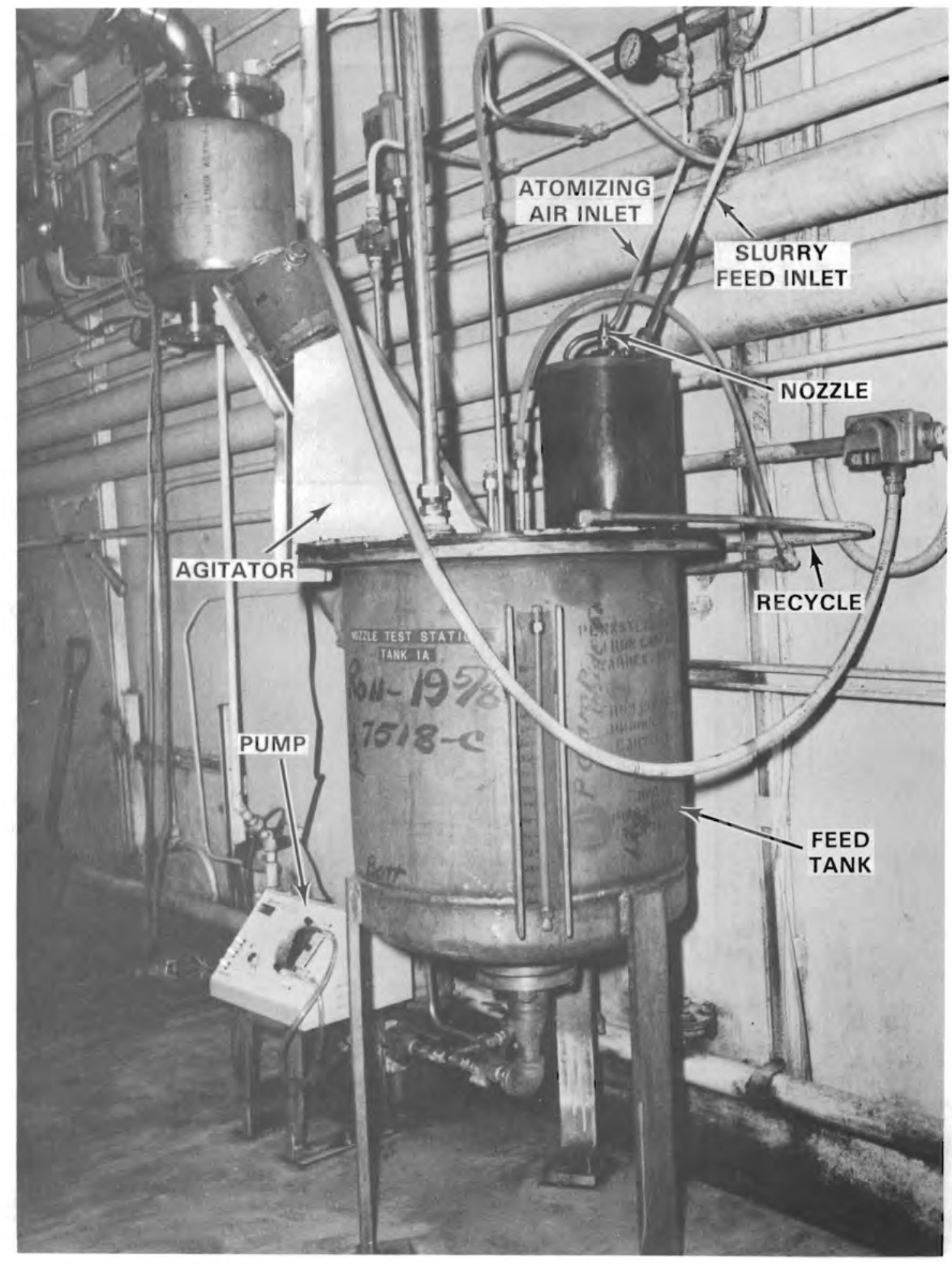

FIGURE 8. Air-Cap Wear Testing Station 
TABLE 5. Simulated Waste Feed Composition

\begin{tabular}{|c|c|c|}
\hline Component & Grams/L & Particle Form in Simulated Feed \\
\hline $\mathrm{Fe}(\mathrm{OH})_{3}$ & 57.7 & Colloidal \\
\hline $\mathrm{Al}(\mathrm{OH})_{3}$ & 13.4 & Nonsoluble Powder ( -200 mesh) \\
\hline $\mathrm{MnO}_{2}$ & 11.4 & Nonsoluble Powder (-200 mesh) \\
\hline Zeolite & 7.3 & Nonsoluble Powder $(-20+80$ mesh $)$ \\
\hline $\mathrm{Ni}(\mathrm{OH})_{2}$ & 6.6 & Nonsoluble Powder ( -200 mesh) \\
\hline $\mathrm{CaCO}_{3}$ & 4.8 & Nonsoluble Powder ( -200 mesh) \\
\hline $\mathrm{SiO}_{2}$ & 3.9 & $-40,+60$ mesh sand \\
\hline $\mathrm{NaNO}_{3}$ & 2.1 & Soluble \\
\hline $\mathrm{Na}_{2} \mathrm{SO}_{4}$ & 1.1 & Soluble \\
\hline
\end{tabular}

Table 6. Due to limitations of the equipment, these conditions do not exactly represent actual spray-calciner run conditions. For comparison purposes, Table 6 also lists a typical set of run parameters for the PNL Pilot-Scale Spray Calciner.

At $15-h$ intervals of accumulated wear time, the air caps were removed from the test station and molds of the air-cap interiors were made. Three molds of the air cap at each time interval were made, and each was marked for orientation to facilitate later comparisons. The mold-forming material used was an RTV rubber type with titanium dioxide added to increase opacity. The mold-forming material was poured into the air caps and then cured on a lowsetting hot plate for about $20 \mathrm{~min}$. This method, using molds of the air-cap interiors, was tested prior to use in this project and has a precision of $0.0025 \mathrm{~cm}$.

\section{THERMAL SHOCK TEST RESULTS}

The thermal shock testing equipment is depicted schematically in Figure 9; a photograph of the equipment is shown in Figure 10. This equipment consisted of a 22.9-cm length of $11.4-\mathrm{cm}$ OD stainless steel pipe with a plate on one end. The pipe was encircled by heating elements, and the whole apparatus insulated. The nozzle assembly fit through an orifice in the plate such that the air cap 
TABLE 6. Wear Testing Run Parameters

\begin{tabular}{|c|c|c|c|c|c|}
\hline \multirow[b]{2}{*}{ Parameter } & \multicolumn{4}{|c|}{ Air-Cap Material } & \multirow{2}{*}{$\begin{array}{c}\text { Pilot-Scale } \\
\text { Spray } \\
\text { Calciner }\end{array}$} \\
\hline & Cer-vit & 303 SS & $96 \% \quad A 120_{3}$ & $\mathrm{Si}_{3} \mathrm{~N}_{4}$ & \\
\hline$\underset{h}{\text { Length of Run, }}$ & 30 & 30 & 60 & 60 & \\
\hline $\begin{array}{l}\text { Average Feed- } \\
\text { Tank Level, } \\
L\end{array}$ & 73 & 70 & 66 & 60 & \\
\hline $\begin{array}{l}\text { Air Pressure, } \\
\text { psig }\end{array}$ & 25 & 25 & 25 & 25 & 40 \\
\hline $\begin{array}{l}\text { Air Flowrate, } \\
\text { scfm }\end{array}$ & 2.5 & 2.5 & 2.5 & 2.5 & 3.0 \\
\hline $\begin{array}{l}\text { Air Flowrate, } \\
L / h\end{array}$ & 4300 & 4300 & 4300 & 4300 & 5100 \\
\hline $\begin{array}{l}\text { Feed Pressure, } \\
\text { psig }\end{array}$ & 15 & 15 & 15 & 15 & 30 \\
\hline $\begin{array}{l}\text { Feed Flowrate, } \\
L / h\end{array}$ & 35 & 35 & 35 & 35 & 20 \\
\hline Pump Used & Centrifugal & Peristaltic & Both & Peristaltic & Centrifugal \\
\hline
\end{tabular}

was located at the top center of the furnace. The temperature of the furnace was controlled by a powerstat, and the temperature of the air cap monitored with a thermocouple connected to a continuous recorder.

Two types of thermal shock tests were performed: rapid cooling and rapid heating. In the rapid-cooling test, the nozzle assembly was placed in the top of the furnace and slowly heated to $2925^{\circ} \mathrm{C}$ before cooled with air to $\sim 200^{\circ} \mathrm{C}$. The starting temperature of $925^{\circ} \mathrm{C}$ was chosen as the highest temperature a nozzle would possibly attain in the event a spray calciner overheated (normal wall temperatures are 700 to $800^{\circ} \mathrm{C}$ ), and as such, represents the "worst-case" condition for thermal shock to the air caps. Use of this temperature will create very large temperature gradients across the air cap; therefore, if the air cap can withstand these thermal shock conditions, it will also withstand shocks under less rigorous conditions. 


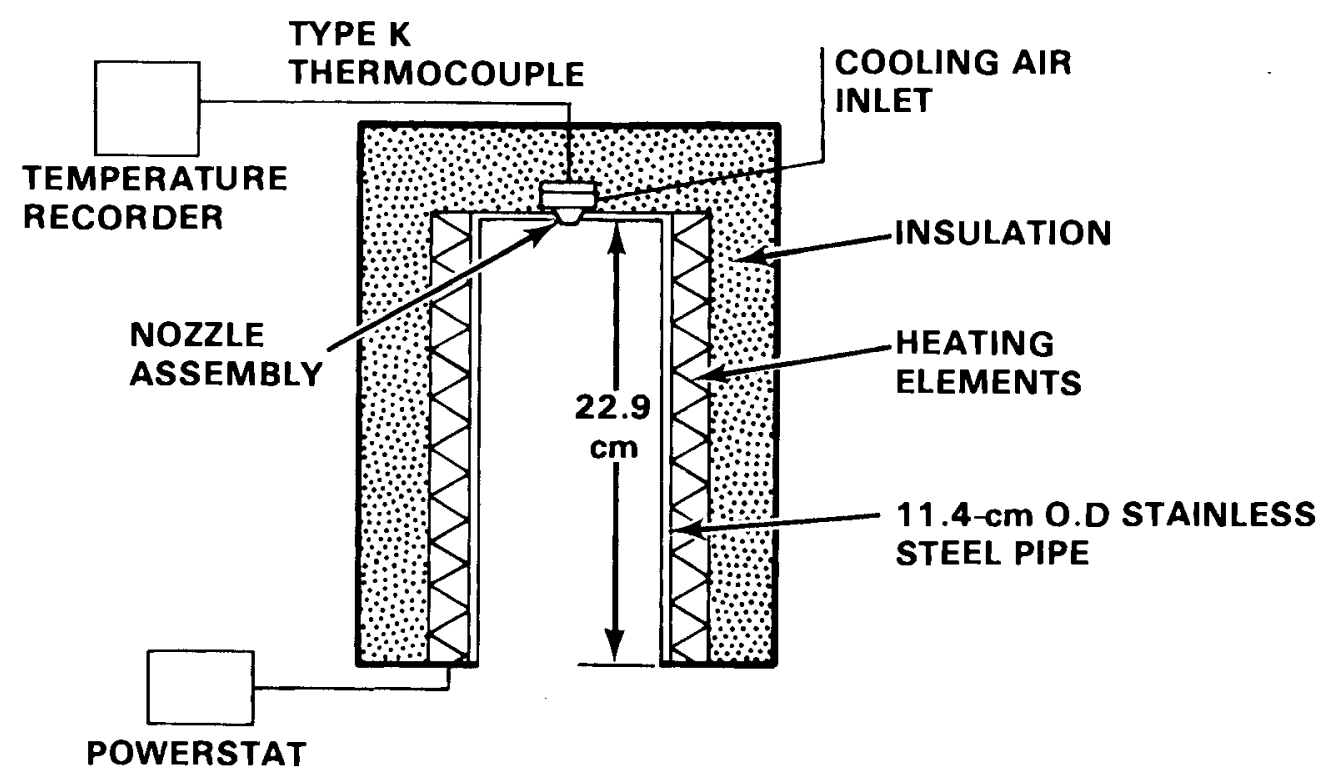

FIGURE 9. Schematic Diagram of Thermal Shock Testing Equipment

Cooling rates ranged from 440 to $1750^{\circ} \mathrm{C} / \mathrm{min}$ which compares favorably to typical thermal shocks experienced in the Pilot-Scale Spray Calciner where the temperature changes about $200^{\circ} \mathrm{C}$ in a few seconds. A complete thermal-shock test run consisted of cooling rates corresponding to 450,750, 1050, 1300, 1600 , and $1750^{\circ} \mathrm{C} / \mathrm{min}$ followed by four shocks in succession at $1750^{\circ} \mathrm{C} / \mathrm{min}$ for a total of 10 shocks. The air caps were inspected after each shock, and if breakage had occurred, no further testing was done on that air cap. Initially, rapid cooling was also done with water, but the cooling rates were not greatly increased. Also, to avoid possible damage of the furnace heating elements from water contact, water was not used further.

In the rapid-heating test, the nozzle assembly at room temperature was $\mathrm{placed}$ into the hot furnace $\left(2925^{\circ} \mathrm{C}\right)$. This proved to be a much less rigorous test than the rapid-cooling test, possibly due to insulation of the air cap by the retaining ring. The maximum initial heating rate was $2200^{\circ} \mathrm{C} / \mathrm{min}$.

Temperature change measurements were made with a Type $\mathrm{K}$ thermocouple located in the mixing chamber portion of the air cap as shown in Figure 11. This location approximates the temperature of the interior surface of the air cap. 


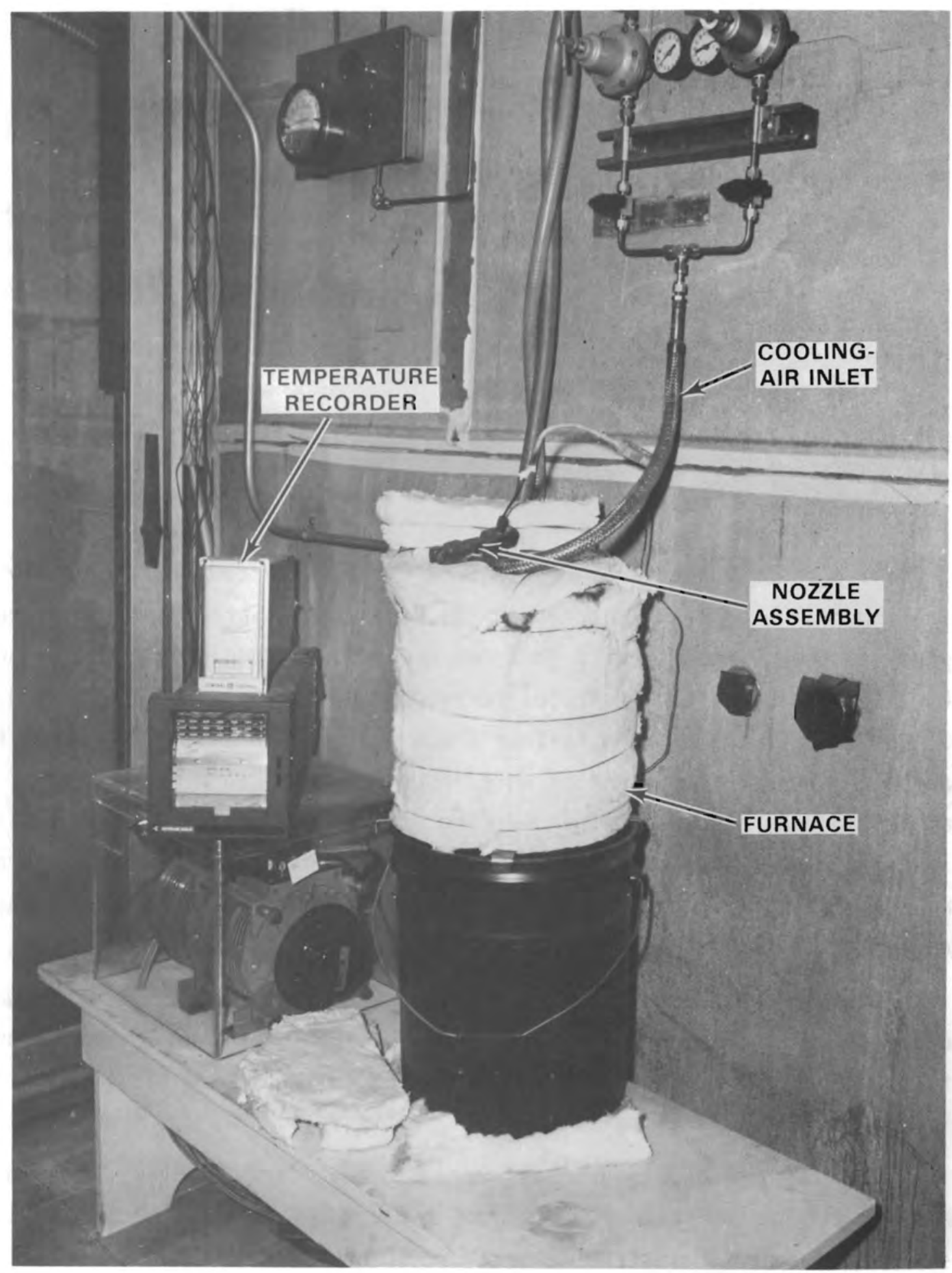

FIGURE 10. Thermal Shock Testing Equipment 


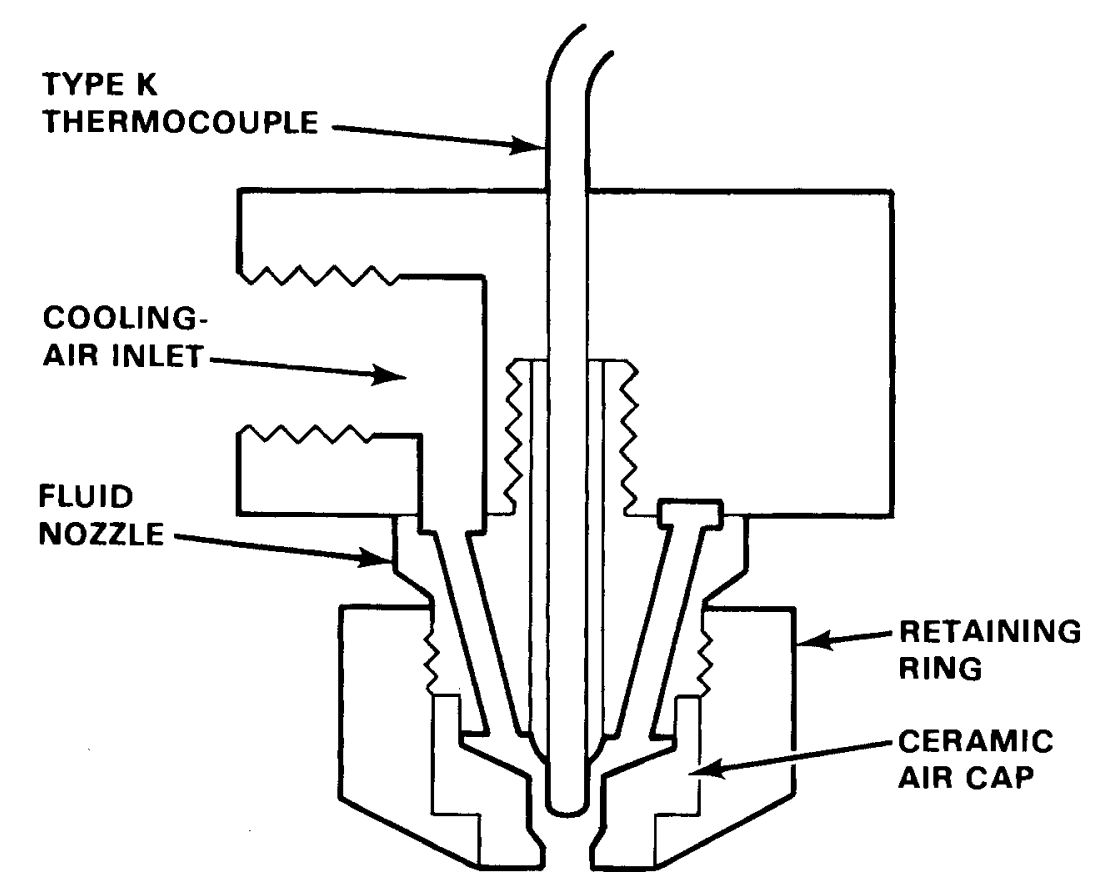

FIGURE 11. Location of Thermocouple in Nozzle Assembly

\section{NOZZLE AIR-CAP MATERIAL TESTS RESULTS}

Results of abrasive-wear testing and shock testing are summarized below. Abrasive Wear Tests Results

Wear measurements taken from molds of nozzles were made to determine: 1) the length of the orifice tip, and 2) the internal orifice diameter at the original orifice tip length. The diagram in Figure 12 illustrates the two measurement locations. The diameter measurements were taken at both $0^{0}$ and $90^{\circ}$ to the orientation mark on the mold. A machinist's $x-y$ microscope and a micrometer, both calibrated to $0.0025 \mathrm{~cm}$ were used for the measurements.

Figure 13 is a photograph of the new and used air caps with the corresponding molds of the interiors. Results of wear measurements in Table 7 show that the orifice tips of the Cer-vit and 303 stainless steel air caps had a 1 arge percent of wear, whereas the $96 \%$ alumina and silicon nitride air caps 


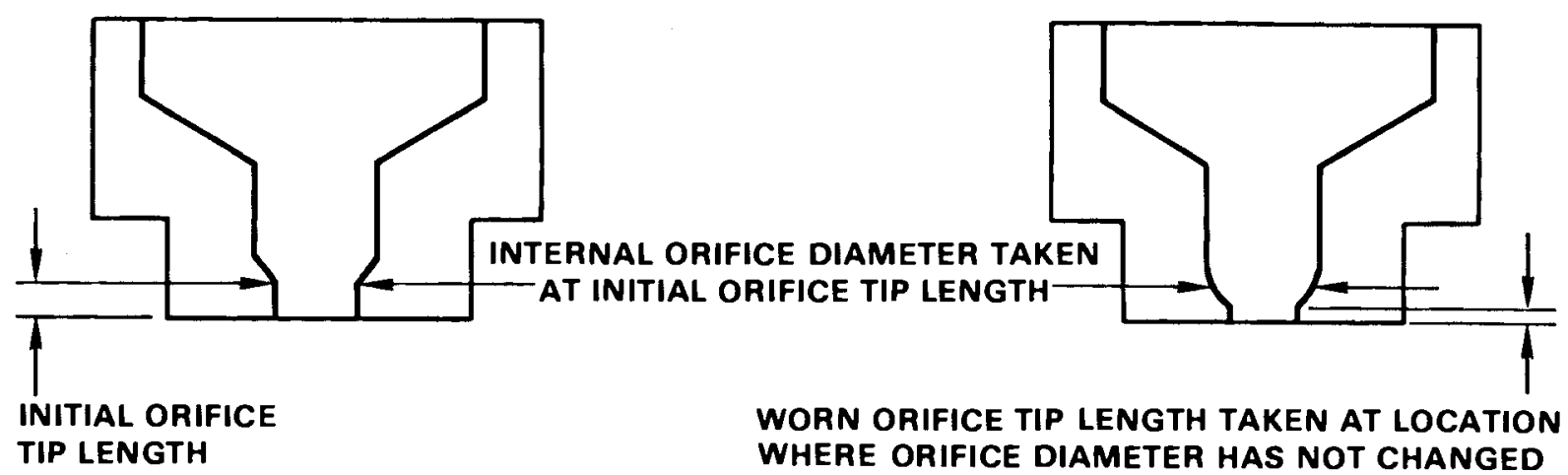

FIGURE 12. Location of Wear Measurements Taken

showed very little wear. The enlarged internal orifice diameter for the alumina air cap in Table 7 cannot be compared to the other three air-cap diameters since this air cap has a different interior configuration (note right-angle entrance to the orifice in Figure 13). Due to this difference, the significant data in Table 7 is the percent of the orifice tip worn through. This percentage is determined as the amount of the initial orifice tip length (see Figure 12) that has an enlarged orifice diameter. In $30 \mathrm{~h}$ of use, 42 and $36 \%$ of the orifice tips of the Cer-vit and 303 stainless steel air caps wore away, respectively, while the $96 \%$ alumina and silicon nitride air caps wore away only 10 to $12 \%$ after $60 \mathrm{~h}$ of use. Significantly, a very slow rate of wear was evident with the alumina and silicon nitride air caps after the first $30 \mathrm{~h}$ of use in which the internal edges were rounded off. After this initial wear, the succeeding $30 \mathrm{~h}$ of use resulted in only 1 to $2 \%$ further wear of the orifice tip. It should be noted that the internal wear on these air caps did not affect their atomizing performance significantly since the exit orifice had not yet sustained any enlargement.

Previous nozzle wear measurements (Bonner, Blair and Romero 1976) that used acid-type waste feeds, such as PW-7-2, show much less wear than indicated in Table 7. The reason is that acid wastes do not contain abrasive solids, such as zeolite and $\mathrm{MnO}_{2}$, which neutralized wastes contain. 


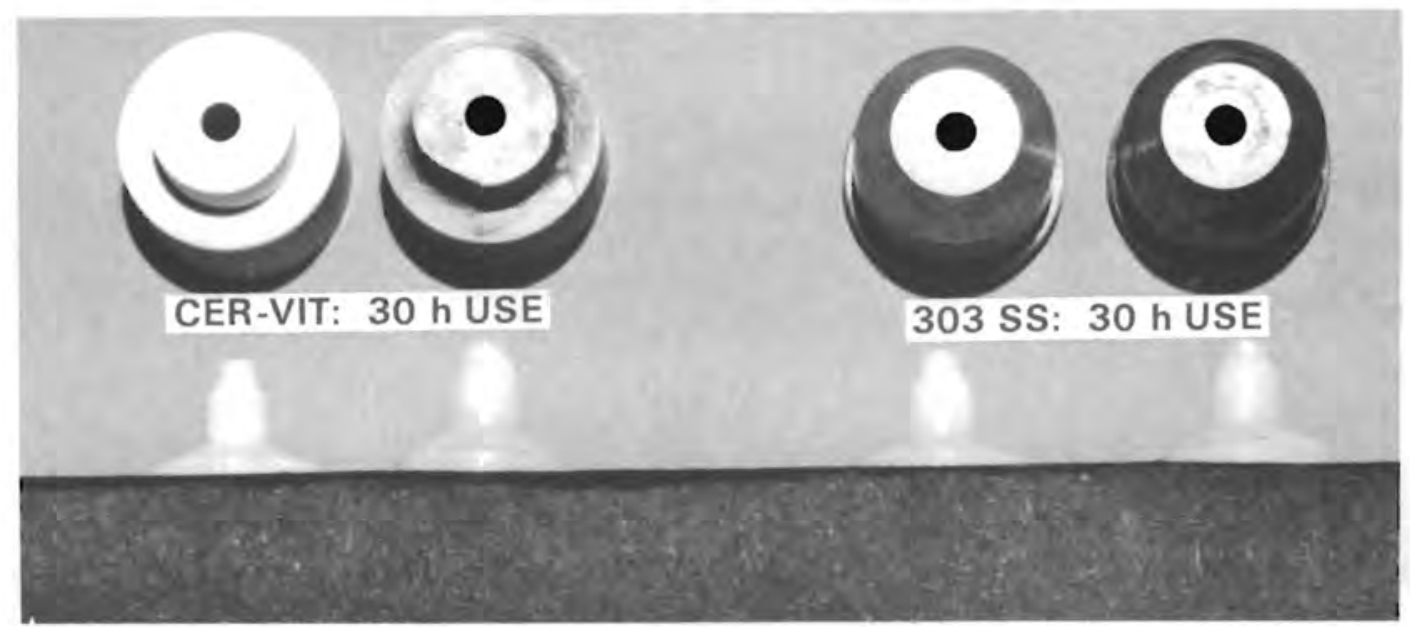

96\% ALUMINA: 60 h USE SILICON NITRIDE: $60 \mathrm{~h}$ USE

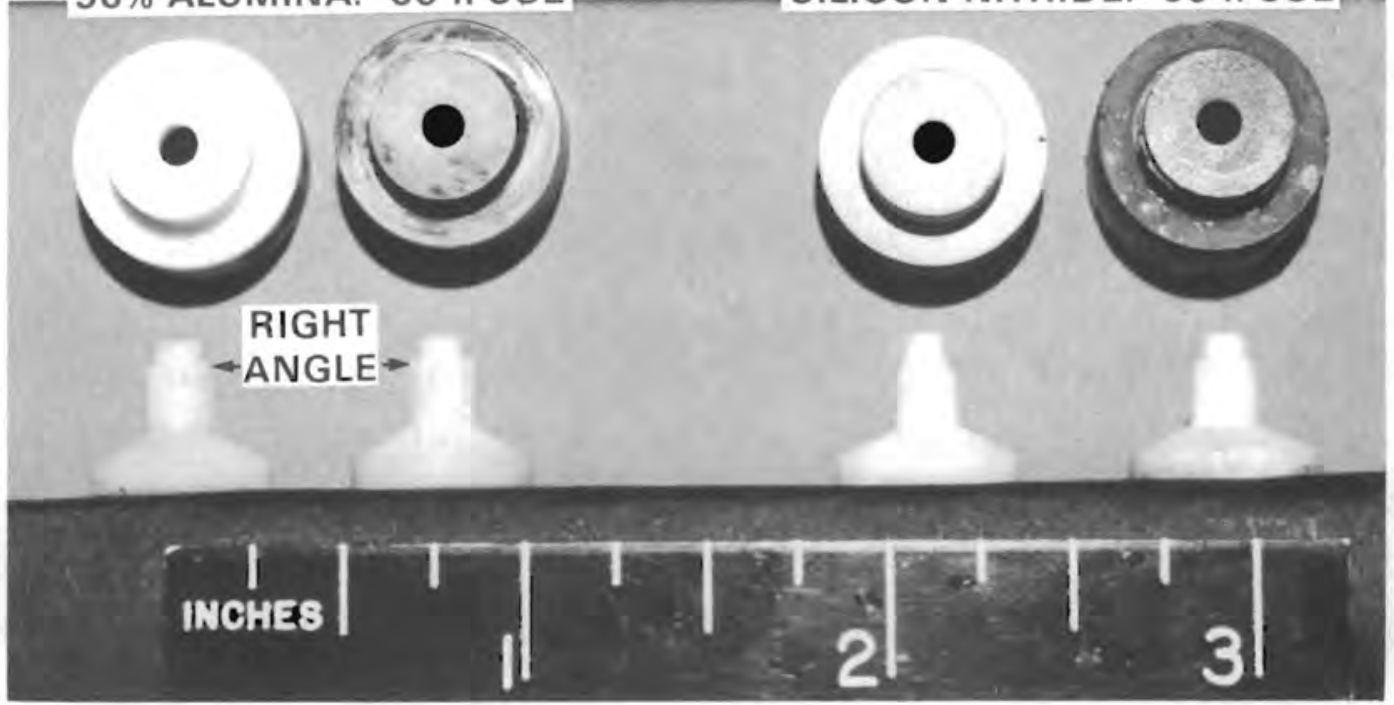

FIGURE 13. New and Worn Air Caps With Corresponding Molds of the Air-Cap Interior

\section{Thermal Shock Tests Results}

The results of the thermal shock tests are listed in Table 8 . As the table shows, the alumina air caps have the greatest variation of breakage conditions. There are a number of possible reasons for this: quality variation, slight density difference, or stresses induced in the air cap during machining. 
TABLE 7. Results of the Abrasive Wear Testing

\begin{tabular}{|c|c|c|c|c|c|c|}
\hline $\begin{array}{c}\text { Air Cap } \\
\text { Composition }\end{array}$ & $\begin{array}{l}\text { Hours } \\
\text { Used }\end{array}$ & $\begin{array}{l}\text { Inter } \\
\text { fice } \\
(\mathrm{cm}) 0 \\
00 \\
\end{array}$ & 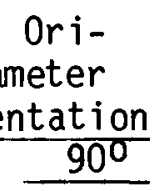 & $\begin{array}{l}\text { Average } \\
\text { Diameter } \\
\text { Increase, } \\
\quad \mathrm{cm}\end{array}$ & $\begin{array}{l}\text { Length of } \\
\text { Orifice } \\
\text { Tip, cm }\end{array}$ & $\begin{array}{l}\% \text { Orific } \\
\text { Tip Worn } \\
\text { Through }\end{array}$ \\
\hline Cer-vit & $\begin{array}{r}0 \\
15 \\
30\end{array}$ & $\begin{array}{l}0.312 \\
0.379 \\
0.401\end{array}$ & $\begin{array}{l}0.312 \\
0.376 \\
0.412\end{array}$ & $\begin{array}{l}-\overline{--} \\
0.064 \\
0.094\end{array}$ & $\begin{array}{l}0.168 \\
0.114 \\
0.097\end{array}$ & $\begin{array}{l}--- \\
32 \\
42\end{array}$ \\
\hline 303 SS & $\begin{array}{r}0 \\
15 \\
30\end{array}$ & $\begin{array}{l}0.315 \\
0.325 \\
0.353\end{array}$ & $\begin{array}{l}0.312 \\
0.323 \\
0.366\end{array}$ & $\begin{array}{l}--- \\
0.010 \\
0.046\end{array}$ & $\begin{array}{l}0.157 \\
0.127 \\
0.102\end{array}$ & $\begin{array}{l}--- \\
19 \\
36\end{array}$ \\
\hline $96 \%$ Alumina & $\begin{array}{r}0 \\
15 \\
30 \\
45 \\
60\end{array}$ & $\begin{array}{l}0.320 \\
0.434 \\
0.470 \\
0.457 \\
0.462\end{array}$ & $\begin{array}{l}0.320 \\
0.467 \\
0.460 \\
0.457 \\
0.465\end{array}$ & $\begin{array}{l}-.-1 \\
0.132 \\
0.145 \\
0.137 \\
0.145\end{array}$ & $\begin{array}{l}0.173 \\
0.157 \\
0.156 \\
0.155 \\
0.152\end{array}$ & $\begin{array}{l}--- \\
9 \\
10 \\
10 \\
12\end{array}$ \\
\hline $\begin{array}{l}\text { Reaction-Bonded } \\
\text { Silicon Nitride }\end{array}$ & $\begin{array}{r}0 \\
15 \\
30 \\
45 \\
60\end{array}$ & $\begin{array}{l}0.320 \\
0.353 \\
0.368 \\
0.373 \\
0.381\end{array}$ & $\begin{array}{l}0.320 \\
0.345 \\
0.366 \\
0.381 \\
0.381\end{array}$ & $\begin{array}{l}-\overline{--} \\
0.028 \\
0.046 \\
0.056 \\
0.061\end{array}$ & $\begin{array}{l}0.175 \\
0.163 \\
0.160 \\
0.157 \\
0.157\end{array}$ & $\begin{array}{r}-- \\
7 \\
9 \\
10 \\
10\end{array}$ \\
\hline
\end{tabular}

Breakage of the Cer-vit air cap in the rapid-heating test may have been due to a flaw since the other two Cer-vit air caps tested did not break under the more rigorous rapid-cooling test. The reaction-bonded silicon nitride air caps tested did not break under any test conditions. Figure 14 is a photograph of the three air caps that broke and an alumina air cap that broke during use in the Pilot-Scale Spray Calciner.

These results indicate that air caps of $96 \%$ alumina are much more susceptible to thermal shock breakage from temperature interruptions than are air caps of either Cer-vit or silicon nitride. However, breakage does not necessarily result in performance failure. Past experience has shown that alumina air caps operate equally as well after thermal shock breakage as before breakage. This is because alumina generally exhibits a very coarse fracture (no splinters), and the pieces are held in place by the retaining ring. This air cap also has no indication of accelerated wear along the cracked surface. 
TABLE 8. Results of the Thermal Shock Testing

\begin{tabular}{|c|c|c|c|c|}
\hline $\begin{array}{l}\text { Air-Cap } \\
\text { Number }\end{array}$ & Material & $\begin{array}{l}\text { Test } P \\
\text { Rapid } \\
\text { Cooling }\end{array}$ & $\begin{array}{c}\text { formed } \\
\text { Rapid } \\
\text { Heating }\end{array}$ & Results \\
\hline 1 & $96 \%$ Alumina & $x$ & & $\begin{array}{l}\text { Broke at initial cooling } \\
\text { rate of } 440^{\circ} \mathrm{C} / \mathrm{min}\end{array}$ \\
\hline 2 & $96 \%$ Alumina & $x$ & & $\begin{array}{l}\text { Broke at initial cooling } \\
\text { rate of } 1790^{\circ} \mathrm{C} / \mathrm{min}\end{array}$ \\
\hline 3 & $96 \%$ Alumina & $x$ & $x$ & Did not break \\
\hline 4 & Cer-vit & $x$ & & Did not break \\
\hline 5 & Cer-vit & & $x$ & $\begin{array}{l}\text { Broke at initial heating } \\
\text { rate of } 200^{\circ} \mathrm{C} / \mathrm{min}\end{array}$ \\
\hline 6 & Cer-vit & $x$ & $x$ & Did not break \\
\hline 7 & $\begin{array}{l}\text { Reaction-Bonded } \\
\text { Silicon Nitride }\end{array}$ & $x$ & & Did not break \\
\hline 8 & $\begin{array}{l}\text { Reaction-Bonded } \\
\text { Silicon Nitride }\end{array}$ & $x$ & $x$ & Did not break \\
\hline 9 & $\begin{array}{l}\text { Reaction-Bonded } \\
\text { Silicon Nitride }\end{array}$ & $x$ & $x$ & Did not break \\
\hline
\end{tabular}

The thermal shock tests also uncovered a flaw in the design of ceramic air caps using the manufacturer's standard dimensions. Ceramic air caps broke around the upper rim as indicated in Figure 15. The thermal expansion coefficients of the stainless steel fluid cap (see Figure 2) and the ceramic air caps were such that the fluid nozzle expanded into the air cap and caused it to break at the weakest point under tensile stress, i.e., at the sharp interior angle. The air cap would still operate in the spray calciner, but the many small pieces created would have the potential of being vibrated out of the air cap to possibly plug the exit orifice. This source of breakage has been eliminated by using an air-cap opening $\sim 2 \% 1$ arger than the manufacturer's standard dimension for stainless stee 1 air caps. 


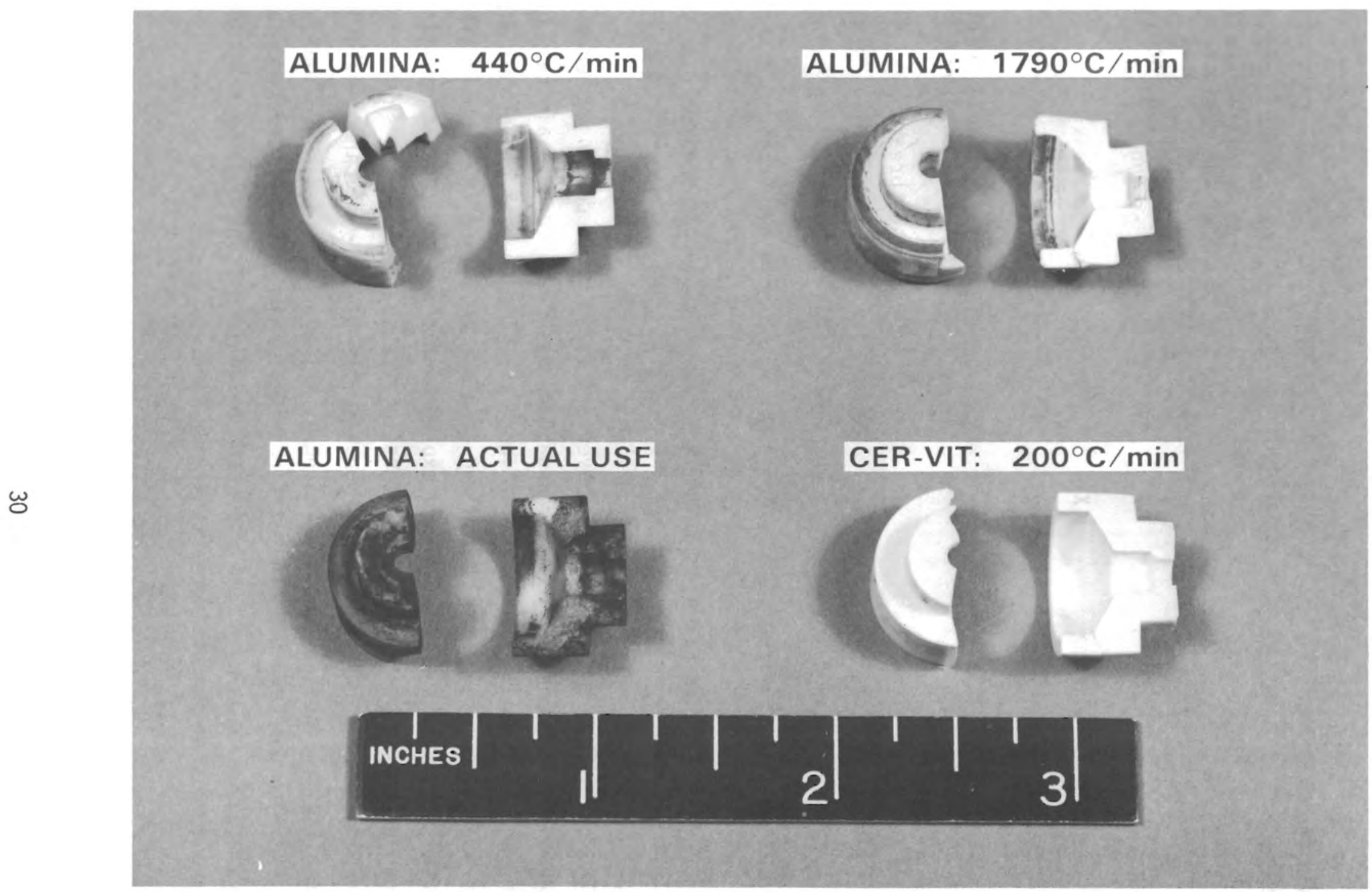

FIGURE 14. Air Caps Broken by Thermal Shock 


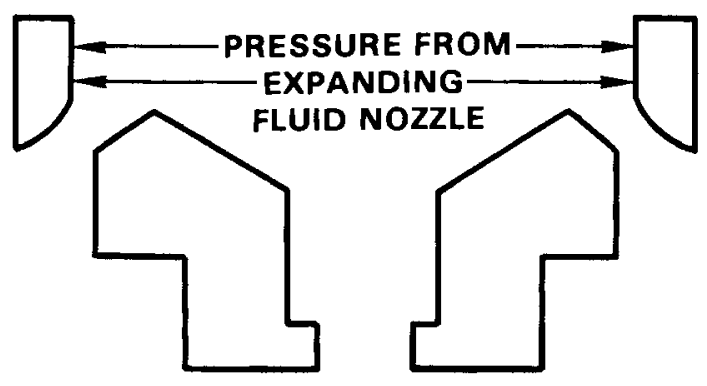

FIGURE 15. Design Failure of Air Caps

\section{FULL-SCALE-CALCINER NOZZLE AIR-CAP WEAR MEASUREMENTS}

Results of wear measurements of nozzle air caps (Spraying Systems Company Set-up No. 82) used during recent full-scale calciner tests are shown in Table 9. The feed-slurry compositions used during operation of these nozzles are given in Table 10. The feed-slurry composition used with the sintered silicon nitride air cap contained a large amount of glass frit for vitrification and thus was more erosive than feeds used for other nozzle-wear tests.

Comparison of full-scale nozzle-wear measurements with measurements made in the tests described previously indicate similar wear for full-scale nozzles of $99 \%$ alumina and pilot-scale nozzles of $96 \%$ alumina. Fourteen percent of the orifice tip was worn through after $100 \mathrm{~h}$ of operation of the full-scale nozzle compared to $12 \%$ of the tip worn through after $60 \mathrm{~h}$ of operation of the pilot-scale nozzle. However, wear measurements for full-scale nozzles of sintered silicon nitride were substantially higher than wear of pilot-scale reaction-bonded silicon nitride $29 \%$ of the orifice tip worn through after $71 \mathrm{~h}$ of operation for the full-scale nozzle compared to $10 \%$ of the nozzle tip worn through after $60 \mathrm{~h}$ for the pilot-scale nozzle). Two reasons for this difference are: 1) the full-scale nozzle was made of sintered silicon nitride, whereas the pilot-scale nozzle was made of reaction-bonded silicon nitride; the two different forming processes likely produced materials of different physical properties; 2) the feed used during operation of the full-scale nozzle contained more solids and was more likely erosive than the feed used during operation of the pilot-scale nozzle. However, the feed flow with the 
TABLE 9. Full-Scale Nozzle(a) Wear Measurements

\begin{tabular}{|c|c|c|c|c|c|c|}
\hline Nozzle Material & $\begin{array}{l}\text { Hours } \\
\text { Used } \\
\end{array}$ & $\begin{array}{c}\text { Average } \\
\text { Feedrate, } \\
\mathrm{L} / \mathrm{h} \\
\end{array}$ & $\begin{array}{c}\text { Average } \\
\text { Internal } \\
\text { Di ameter, } \\
\quad \mathrm{m} \\
\end{array}$ & $\begin{array}{l}\text { Average } \\
\text { Di ameter } \\
\text { Increase, } \\
\quad \mathrm{mm} \\
\end{array}$ & $\begin{array}{l}\text { Length } \\
\text { of Orifice } \\
\text { Tip, mm } \\
\end{array}$ & $\begin{array}{l}\% \text { of } \\
\text { Orifice } \\
\text { Tip Worn }\end{array}$ \\
\hline $99 \%$ Alumina & $\begin{array}{r}0 \\
100\end{array}$ & $\overline{190}$ & $\begin{array}{l}7.95 \\
9.05\end{array}$ & $\overline{1 .-10}$ & $\begin{array}{l}4.00 \\
3.44\end{array}$ & $\overline{14.0}$ \\
\hline $\begin{array}{l}\text { Sintered Silicon } \\
\text { Nitride }\end{array}$ & $\begin{array}{r}0 \\
71\end{array}$ & $\begin{array}{r}-- \\
93\end{array}$ & $\begin{array}{l}7.90 \\
9.29\end{array}$ & $\overline{1 .-}$ & $\begin{array}{l}3.65 \\
2.61\end{array}$ & $\begin{array}{l}--- \\
28.6\end{array}$ \\
\hline
\end{tabular}

(a) Spraying Systems Company Set-up No. 82 nozzle [air-cap or if ice diameter = $0.793 \mathrm{~cm}(0.312$ in. $)]$.

TABLE 10. Feed Slurry Composition Used During Nozzle-Wear Measurement Tests

\begin{tabular}{|c|c|c|c|}
\hline \multirow{2}{*}{\multicolumn{2}{|c|}{$\begin{array}{l}\text { Feed Atomized by } \\
\text { 99\% Alumina Nozzle }\end{array}$}} & \multicolumn{2}{|c|}{ Silicon Nitride Nozzle } \\
\hline & & Chemical & $\begin{array}{c}\text { Chemical Form, } \\
\mathrm{g} / \mathrm{L}\end{array}$ \\
\hline $\mathrm{Fe}(\mathrm{OH})_{3}$ & 69.73 & $\mathrm{Fe}(\mathrm{OH})_{3}$ & 52.37 \\
\hline $\mathrm{Al}_{2} \mathrm{O}_{3} \cdot 3 \mathrm{H}_{2} \mathrm{O}$ & 17.49 & $\mathrm{Al}(\mathrm{OH})_{3}$ & 13.14 \\
\hline $\mathrm{MnO}_{2}$ & 13.92 & $\mathrm{MnO}_{2}$ & 10.45 \\
\hline $\mathrm{CaCO}_{3}$ & 6.35 & $\mathrm{CaCO}_{3}$ & 4.77 \\
\hline $\mathrm{NiO} \cdot 2 \mathrm{H}_{2} \mathrm{O}$ & 8.99 & $\mathrm{NiO} \cdot 2 \mathrm{H}_{2} \mathrm{O}$ & 6.75 \\
\hline $\mathrm{NaNO}_{3}$ & 2.93 & $\mathrm{NaNO}_{3}$ & 2.20 \\
\hline $\mathrm{Na}_{2} \mathrm{SO}_{4}$ & 1.43 & $\mathrm{Na}_{2} \mathrm{SO}_{4}$ & 1.07 \\
\hline Zeolite & 10.35 & Zeolite & 1.77 \\
\hline $\mathrm{Na}-\mathrm{EDTA}$ & 8.10 & Cornstarch & 0.43 \\
\hline Cornstarch & 0.57 & Coal & 2.17 \\
\hline Anthracite Coal & 2.89 & Frit-211 & 192.9 \\
\hline $\mathrm{NaCl}(\mathrm{a})$ & 1.6 & TOTAL & 294.0 \\
\hline $\mathrm{NaF}$ & 0.178 & & \\
\hline $\mathrm{CsNO}_{3}$ & 0.071 & & \\
\hline $\mathrm{Sr}\left(\mathrm{NO}_{3}\right)_{2}$ & 0.071 & & \\
\hline TOTAL & 144.7 & & \\
\hline
\end{tabular}


full-scale silicon nitride nozzle was much lower than normal, and the difference in the formation of the ceramic is expected to have been the major cause of the variation of the wear measurements. Therefore, the method of ceramic formation must be considered in addition to the type of ceramic used. Apparently, reaction-bonded silicon nitride has superior wear characteristics compared to sintered silicon nitride. Hot-pressed silicon nitride, formed at high temperatures and pressures (this material was not tested), may be superior to reaction-bonded silicon nitride in wear resistance based on the comparison of physical properties in Table 11.

\section{OPERATING-L IFE ESTIMATES}

Occasional replacement of the atomizing nozzle air cap on spray calciners will be necessary due to gradual wear of the air-cap orifice. Enlargement of the orifice can be detected by increased air and feed flowrates at particular pressures.

Since the performance of the atomizing nozzle does not change significantly until the downstream diameter of the air-cap orifice becomes enlarged, the expected working life of the nozzle can be estimated from extrapolations of the wear measurements presented in Tables 8 and 9. Figure 16 shows the actual wear measurements in percent of the nozzle air-cap tip worn through for

TABLE 11. Comparison of Physical Properties for Reaction-Bonded and HotPressed Silicon Nitride

\begin{tabular}{|c|c|c|c|}
\hline \multirow[b]{2}{*}{ Material } & \multicolumn{2}{|c|}{ Property } & \multirow{2}{*}{$\begin{array}{c}\text { Compressive } \\
\text { Strength }\end{array}$} \\
\hline & Density & Modulus of $\mathrm{Ru}$ & \\
\hline $\begin{array}{l}\text { eaction-Bonded(a) } \\
\text { ilicon Nitride }\end{array}$ & Up to $2.7 \mathrm{~g} / \mathrm{cm}^{3}$ & 30,000 psi & $77,000-112,000$ psi \\
\hline $\begin{array}{l}\text { Hot-Pressed }(b) \\
\text { Silicon Nitride }\end{array}$ & $.11 \mathrm{~g} / \mathrm{cm}^{3}$ & $70,000-120,000 \mathrm{psi}$ & $300,000-500,000$ \\
\hline
\end{tabular}

(a) Product data from KBI-AME, Inc., bullet in file number 600 PDI-13.

(b) Product data from Ceradyne, Inc., Cerolloy 147A silicon nitride. 


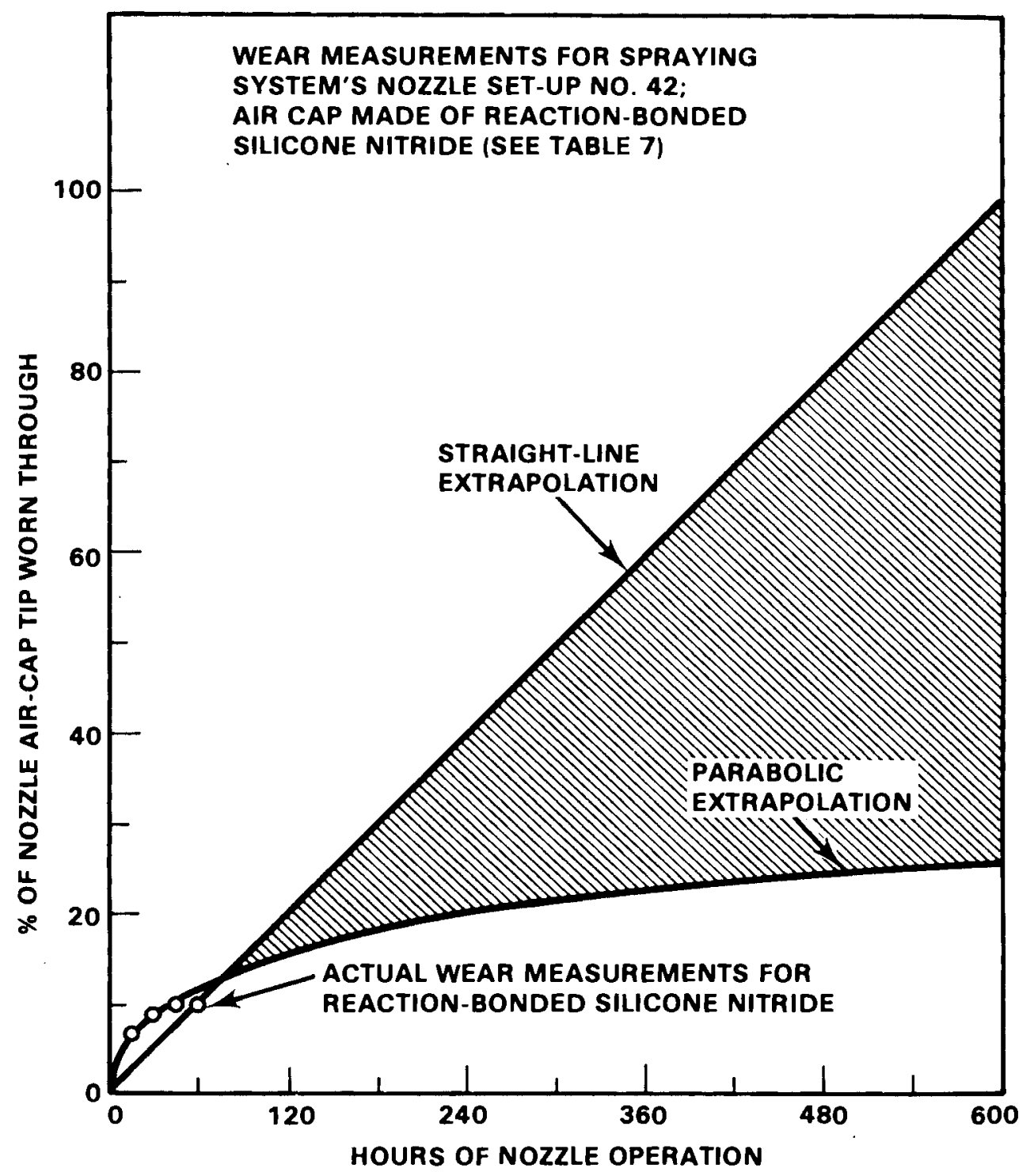

FIGURE 16. Nozzle Air-Cap Operating Life Extrapolation

the reaction-bonded silicon nitride versus hours of operation. The measuredwear data are then extrapolated by two different methods--a straight-line extrapolation and a parabolic extrapolation that follows the curvature of the measured data points. These two methods of extrapolation predict widely varying results--600 $\mathrm{h}(25 \mathrm{~d})$ of operation for the straight-line extrapolation compared to several months of operation for the parabolic extrapolation. Obviously, longer-term testing ( $>25 \mathrm{~d}$ ) is required to more accurately determine the actual frequency of nozzle replacement. 
At this time, it can be concluded that a nozzle with an air cap of reaction-bonded silicon nitride will perform satisfactorily for at least $25 \mathrm{~d}$ and likely up to several months before replacement is required. In addition, hotpressed silicon nitride is expected to have superior wear characteristics to reaction-bonded silicon nitride, based on the properties listed in Table 11, which would decrease even further the frequency of nozzle replacement required. 


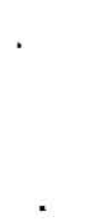




\section{REFERENCES}

Bonner, W. F., H. T. Blair and L. S. Romero. 1976. Spray Solidification of Nuclear Waste. BNWL-2059, Pac ific Northwest Laboratory, Richland, Washington.

Kanfmah, F. et a7. 1976. Recent Experience With Steam-Heated Spray Calcining Unit for HLW Solidification. Presented at the AIChE 68th Annual Meeting, Los Angeles, California, November 16-20, 1976.

Kaser, J. D. 1969. Evaluation of Atomizing Nozzles for the Spray Solidification of Radioactive Waste. BNWL-1066, Pacific Northwest Laboratory, Richland, Washington. 
. 


\section{DISTRIBUTION}

No. of

Copies

OFFSITE
A. A. Churm
DOE Chicago Patent Group
9800 South Cass Avenue
Argonne, IL 60439

2 R. Y. Lowrey

DOE ATbuquerque Operations Office

P. 0. Box 5400

Albuquerque, NM 87185

A. L. Taboas

DOE Albuquerque Operations Office

P. 0. Box 5400

Albuquerque, NM 87185

S. A. Mann

DOE Chicago Operations and Region Office

Argonne, IL 60439

\section{J. 0. Neff}

Department of Energy

Columbus Program office

505 King Avenue

Columbus, $\mathrm{OH} 43201$

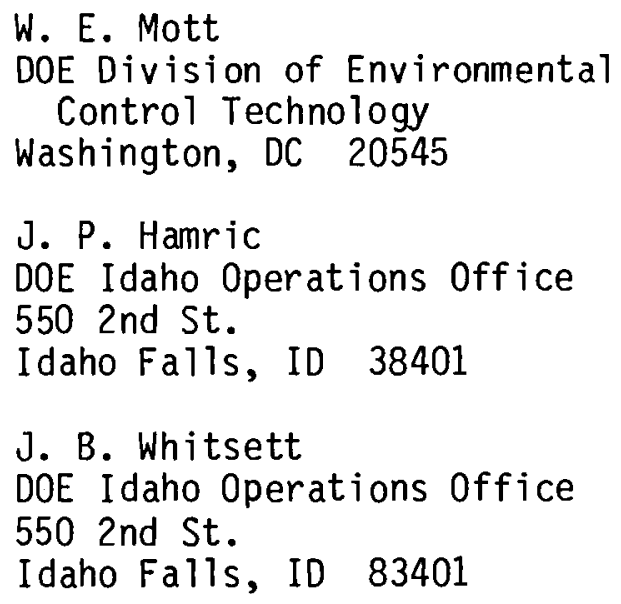

W. E. Mott

DOE Division of Environmental Control Technology

Washington, DC 20545

J. P. Hamric

DOE Idaho Operations office

550 2nd St.

Idaho Falls, ID 38401

J. B. Whitsett

DOE Idaho Operations office

550 2nd St.

Idaho Falls, ID 83401

No. of

Copies

D. G. Boyer

DOE Nuclear Waste Management Programs

NE-331, GTN

Washington, DC 20545

R. Chitwood

DOE Nuclear Waste Management Programs

NE-341, GTN

Washington, DC 20545

C. R. Cooley

DOE Nuclear Waste Management Programs

NE-331, GTN

Washington, DC 20545

G. H. Daly

DOE Nuclear Waste Management Programs

NE-322, GTN

Washington, DC 20545

J. E. Dieckhoner

DOE Nuclear Waste Management Programs

NE-321, GTN

Washington, DC 20545

C. H. George

DOE Nuclear Waste Management Programs

NE-342, GTN

Washington, DC 20545

C. A. Heath

DOE Nuclear Waste Management Programs

NE-330, GTN

Washington, DC 20545 
No. of

Copies

M. L. Lawrence

DOE Nuclear Waste Management Programs

NE-340, GTN

Washington, DC 20545

D. J. McGoff

DOE Nuclear Waste Management Programs

NEW, B-107, HQ

Washington, DC 20545

2 S. Meyers

DOE Nuclear Waste Management

Programs

NE-30, GTN

Washington, DC 20545

G. Oertel

DOE Nuclear Waste Management Programs

NE-320, GTN

Washington, DC 20545

5 A. F. Perge

DOE Nuclear Waste Management Programs

NE-301, GTN

Washington, DC 20545

R. W. Ramsey, Jr.

DOE Nuclear Waste Management

Programs

NE-301, GTN

Washington, DC 20545

R. Romatowski

DOE Nuclear Waste Management

Programs

NE-30, GTN

Washington, DC 20545

V. Trice

DOE Nuclear Waste Management Program

NEW, B-107, HQ

Washington, DC 20545
No. of

Copies

D. L. Vieth

DOE Nuclear Waste Management

Programs

NE-332, GTN

Washington, DC 20545

2 S. W. Ahrends

DOE Oak Ridge Operations Office

P. 0. Box E

Oak Ridge, TN 37830

D. E. Large

DOE Oak Ridge Operations Office

P. 0. Box E

Oak Ridge, TN 37830

S. G. Harbinson

DOE San Francisco Operations Office

1333 Broadway

Oak land, CA 94612

E. S. Goldberg

DOE Savannah River Operations Office

P. 0. Box A

Aiken, SC 29801

W. B. Wilson

DOE Savannah River Operations Office

P. 0. Box A

Aiken, SC 29801

R. P. Whitfield

DOE Savannah River Operations Office

P. 0. Box A

Aiken, SC 29801

Los Alamos Scientific Laboratory

P. 0. Box 1663

Los Alamos NM 87544

J. B. Martin

Division of Waste Management Nuclear Regulatory Commission Washington, DC 20555 
No. of

Copies

D. B. Rohrer

Division of Waste Management Nuclear Regulatory Commission Washington, DC 20555

R. D. Smith

- Division of Waste Management Nuclear Regulatory Commission Washington, DC 20555

R. E. Cunningham

Office of Nuclear Safety Materials and Safeguards Nuclear Regulatory Commission Room 562, 7915 Eastern Avenue Silver Springs, MD 20910

27 DOE Technical Information Center

J. A. Buckham

Allied-General Nuclear Services

P. 0. Box 847

Barnwe11, SC 29812

A. Williams

Allied-General Nuclear Services P. 0. Box 847

Barnwell, SC 29812

J. W. Bartlett

The Analytical Sciences Corp. 6 Jacob Way

Reading, MA 01867

J. H. Kittel

Argonne National Laboratory

Office of Waste Management Programs

9700 South Cass Avenue

Argonne, IL 60439

M. J. Steindler/L. E. Trevorrow Argonne National Laboratory 9700 South Cass Avenue

Argonne, IL 60439
No. of

Copies

A. Brandstetter

Battelle Memorial Institute

Office of Nuclear Waste

Isolation

505 King Avenue

Columbus, $\mathrm{OH} 43201$

W. Carbiener

Battelle Memorial Institute

Office of Nuclear Waste Isolation

505 King Avenue

Columbus, $\mathrm{OH} 43201$

N. E. Carter

Battelle Memorial Institute

Office of Nuclear Waste Isolation

505 King Avenue

Columbus, $\mathrm{OH} 43201$

P. L. Hofmann

Battelle Memorial Institute

Office of Nuclear Waste Isolation

505 King Avenue

Columbus, $\mathrm{OH} 43201$

M. Kehnemuyi

Battelle Memorial Institute

Office of Nuclear Waste Isolation

505 King Avenue

Columbus, $\mathrm{OH} 43201$

Beverly Rawles

Battelle Memorial Institute

Office of Nuclear Waste Isolation

505 King Avenue

Columbus, $\mathrm{OH} 43201$

Research Library

Battelle Memorial Institute $505 \mathrm{King}$ Avenue

Columbus, $\mathrm{OH} 43201$ 
No. of

Copies

R. Maher, Program Manager Waste Management Programs Savannah River Plant

E. I. Du Pont de Nemours \& Co. Aiken, SC 29801

W. H. Baker

E. I. Du Pont de Nemours \& Co. Savannah River Laboratory

Aiken, SC 29801

M. D. Boersma

E. I. Du Pont de Nemours \& Co. Savannah River Laboratory

Aiken, SC 29801

J. L. Crandall

E. I. Du Pont de Nemours \& Co. Savannah River Laboratory

Aiken, SC 29801

R. G. Garvin

E. I. Du Pont de Nemours \& Co. Savannah River Laboratory

Aiken, SC 29801

L. W. Meyer

E. I. Du Pont de Nemours \& Co. Savannah River Laboratory

Aiken, SC 29801

D. L. McIntosh

E. I. Du Pont de Nemours \& Co. Savannah River Laboratory

Aiken, SC 29801

S. Mirshak

E. I. Du Pont de Nemours \& Co. Savannah River Laboratory

Aiken, SC 29801

J. A. Porter

E. I. Du Pont de Nemours \& Co. Savannah River Laboratory

Aiken, SC 29801
No. of

Copies

A. L. Ayers

EG \& G Idaho

P. 0. Box 1625

Idaho Falls, ID 83415

G. B. Levin

EG \& G Idaho

P. 0. Box 1625

Idaho Falls, ID 83415

R. Williams

Electric Power Research Institute

3412 Hillview Avenue

Palo Alto, CA 94304

J. L. Larocca, Chairman

Engineering Research and Development Authority

Empire State Plaza

Albany, NY 12223

2 Environmental Protection Agency

Technological Assessment Division (AW-559)

Office of Radiation Programs

U.S. Environmental Protection Agency

Washington, DC 20460

D. M. Rosenbaum

Office of Radiation Programs

U.S. Environmental Protection Agency

1921 Jefferson Davis Highway

Arlington, VA 22202

J. R. Berreth

Exxon Nuclear Idaho

P. 0. Box 2800

Idaho Falls, ID 83401

G. L. Ritter

Exxon Nuclear Idaho

P. 0. Box 2800

Idaho Falls, ID 83401 
No. of

Copies

File Copy

Exxon Nuclear Idaho

P. 0. Box 2800

Idaho Falls, ID 83401

G. E. Benedict

General Atomics Co.

P. 0. Box 81608

San Diego, CA 92138

L. H. Brooks

Gulf Energy and Environmental Systems

P. 0. Box 81608

San Diego, CA 92138

3 J. Campbell

Lawrence Livermore Laboratory

P. 0. Box 808

Livermore, CA 94550

J. D. Tewhey

Lawrence Livermore Laboratory

P. 0. Box 808

Livermore, CA 94550

R. Roy

202 Materials Research Laboratory

Pennsylvania State University

University Park, PA 16802

C. J. Kershner

Monsanto Research Corporation

Mound Laboratory

P. 0. Box 32

Miamisburg, OH 45342

J. P. Duckworth

Plant Manager

Nuclear Fuels Services, Inc.

P. 0. Box 124

West Valley, NY 14171

R. E. Bl anco

Oak Ridge National Laboratory

P. 0. Box $Y$

Oak Ridge, TN 37830
No. of

Copies

J. 0. Blomeke

Oak Ridge National Laboratory

P. 0. Box $Y$

Oak Ridge, TN 37830

D. E. Ferguson

Oak Ridge National Laboratory

P. 0. Box $Y$

Oak Ridge, TN 37830

3 A. L. Lotts

Oak Ridge National Laboratory

P. 0. Box $X$

Oak Ridge, TN 37830

R. S. Lowrie

Oak Ridge National Laboratory

P. 0. Box $Y$

Oak Ridge, TN 37830

2 A. B. Martin

Rockwell International

Energy Systems Group

8900 DeSoto Avenue

Canoga Park, CA 91304

H. Recht

Dept. 737-710

Atomics International Division

Rockwell International

Box 309

Canoga Park, CA 91304

W. S. Bennett

Rockwe 11 International

Rocky Flats Plant

P. 0. Box 464

Golden, C0 80401

Paul Hagen

Chemical Operations

Rockwell International

Rocky Flats Plant

P. 0. Box 464

Golden, C0 80401 
No. of

Copies

D. R. Anderson

Sandia Laboratories

Albuquerque, NM 87185

0 . E. Jones

Sandia Laboratories

Albuquerque, NM 87185

R. G. Kepler

Organic and Electronic

Dept. 5810

Sandia Laboratories

Albuquerque, NM 87185

W. Weart

Sandia Laboratories

Albuquerque, NM 87185

D. E. Harrison

Westinghouse Electric Corp.

P. 0. Box 355

Pittsburgh, PA 15230

P. B. Macedo

Keane Hall

Vitreous State Laboratory

The Catholic University of America

Washington, DC 20017

R. G. Post

College of Engineering

University of Arizona

Tucson, AZ 85721

L. L. Hench

Dept. of Materials Science

and Engineering

University of Florida

Gainesville, FL 32611

Dr. Hayne Palmour III

2140 Burlington Engineering Laboratories

North Carolina State University

Raleigh, NC 27607
No. of

Copies

F. K. Pittman

3508 Sagecrest Terrace

Ft. Worth, TX 76109

ONSITE

4 DOE Richland Operations Office

P. A. Craig (2)

R. E. Gerton

H. E. Ransom

4 Rockwell Hanford Operations

I. E. Reep

D. D. Wodrich (3)

UNC United Nuclear Industries

F. H. Bouse

West inghouse Hanford Company

A. G. Blasewitz

73 Pacific Northwest Laboratory

S. M. Barnes

W. J. Bjorklund

H. T. Blair

W. F. Bonner

D. J. Bradley

A. Brandstetter

D. W. Brite

R. A. Brouns

J. L. Buelt

R. L. Bunnel1

J. R. Carrel1

J. G. Carter

D. B. Cear lock

L. A. Chick

T. D. Chikalla

M. 0. Cloninger

R. D. Dierks

G. J. Exarhos 
No. of

Copies

Pacific Northwest Laboratory (contd)

J. W. Finnigan

W. J. Gray

C. R. Hann

M. S. Hanson

A. J. Haverfield

O. F. Hill

L. K. Holton

J. H. Jarrett

Y. B. Katayama

W. S. Kelly

R. S. Kemper

D. E. Knowlton

C. A. Knox

W. L. Kuhn

L. T. Lakey

D. E. Larson

J. M. Latkovich

R. 0. Lokken

G. B. Long (3)

R. P. Marshal1

J. L. McElroy

G. B. Mellinger

J. E. Mende 1

R. D. Nelson

J. F. Nesbitt

R. E. Nightingale

D. E. Olesen

P. J. Pelto

R. D. Peters

L. L. Petkus

A. M. Platt

D. L. Prezbindowski (2)

F. P. Roberts

W. A. Ross

J. M. Rusin

D. H. Siemens

S. C. Slate

C. L. Timmerman

R. L. Treat

R. P. Turcotte

H. H. Van Tuy 1

B. E. Vaughan
No. of

Copies

Pac if ic Northwest Laboratory (contd)

J. W. Wald/W. E. Weber

J. H. Westsik, Jr.

L. D. Williams

Technical Information (5)

Publishing Coordination EI (2) 
